\title{
ASPECTOS DA DISPERSÃO DE TRÊS ESPÉCIES DE CICADELÍDEOS (HEMIPTERA:CICADELLIDAE) DOS CITROS
}

\section{CíCero AleXandre Leite}

(Engenheiro Agrônomo)

Orientador prof. Dr. OCTAVIo NAKano

Dissertação apresentada à Escola Superior de Agricultura "Luiz de Queiroz", Universidade de São Paulo, para obtenção do título de Mestre em Ciências, Área de Concentração Entomologia.

P I R A C I C A B A

Estado de São Paulo-Brasil

Outubro 1999 
Dados Internacionais de Catalogação na Publicação (CIP)

DIVISĀo DE BIBLIOTECA E DOCUMENTAÇĀO - Campus “Luiz de Queiroz"/USP

\section{Leite, Cicero Alexandre} Aspectos da dispersão de três espécies de cicadelideos (Hemiptera: Cicadellidae) dos citros / Cícero Alexandre Leite. - - Piracicaba, 1999.

\section{$70 \mathrm{p}$.}

Dissertação (mestrado) - Escola Superior de Agricultura Luiz de Queiroz, 1999. Bibliografia.

1. Cicadelídeo 2. Cigarrinha 3. Clorose-variegada-dos-citros 4. Dispersāo 5, Fruta citrica 6. Inseto-nocivo 7. Praga agricola I. Título 


\section{ASPECTOS DA DISPERSÃO DE TRÊS ESPÉCIES DE CICADELÍDEOS (HEMIPTERA:CICADELLIDAE) DOS CITROS}

CÍCERO ALEXANDRE LEITE

Aprovado em: 9/12/1999

Comissão julgadora:

Prof. Dr. Octavio Nakano

Prof. Dr. João Roberto Spoti Lopes

ESALQ/USP

Dr. Pedro Takao Yamamoto

ESALQ/USP

FUNDECITRUS

Prof. OCTAVIO NAKANO

Orientador 


\section{ERRATA}

Na página vi, no item 2.2 e no item 2.3.2, onde está escrito "Xilella", leia -se "Xylella".

Na página vi, no item 2.4, onde está escrito "epidemeologia", leia -se "epidemiologia".

Na página vi, no item 3.4, onde está escrito "cicacadelídeos", leia -se "cicadelídeos".

Na página xii, na linha 15 , onde está escrito " $20 \mathrm{~km} / \mathrm{h}$ ", leia-se " $21 \mathrm{~m} / \mathrm{s} "$.

Na página xiv, na linha 14, onde está escrito "20 km/h", leia-se " $21 \mathrm{~m} / \mathrm{s} "$.

Na página 2 , na linha 14, onde está escrito "... Xylella fastidiosa (Wells et al., 1987; Leite Junior...", leia -se "... Xylella fastidiosa Wells et al., 1987. ( leite Junior...".

$\mathrm{Na}$ página 13 , na linha 5 , onde está escrito "...citros é considerada...", leia-se "citros não é considerada...".

Na página 22, na linha 3, onde está escrito "...cartões adesivos amarelo...", leia-se "...cartões adesivos amarelo-ouro e amarelo-limão..."

Na página 24 , onde está escrito "7,6\%", leia-se "30,8\%".

Nas páginas 25,26 e 27 , nos títulos das tabelas 1,2 e 3 , leia-se "número indivíduos de...".

Nas páginas 25, 26 e 27, nos títulos dos eixos $\mathrm{X}$ das figuras 1, 2, e 3, leia-se Distância $\left(\mathrm{m}^{2}\right)$.

Na página 42, na linha 10, onde está escrito "(figura 21)", leia-se "(figura 12)".

Na página 46, em local e horário de pouso dos cicadelídeos dos citros, onde está escrito "... diferenças de pousos...", leia-se "...diferenças de locais de pousos...".

Na página 47, na linha 1, leia-se "A Grande maioria das cigarrinhas preferiram pousar nos terços médio e superior nas folhas novas e também nas velhas".

Nas página 49, no título do eixo Y da figura 18, leia-se "Número de cigarrinhas", e no título do eixo $\mathrm{X}$, leia-se "representação vertical da planta cítrica".

Na página 53, na linha 2 de Ação do vento na dispersão dos cicadelídeos dos citros, onde está escrito " $12 \mathrm{~km} / \mathrm{h}$ ", leia-se " $12 \mathrm{~m} / \mathrm{s} "$.

Na página 54, no título da Tabela 6, leia-se "Número de Indivíduos de Oncometópia facialis retirados das folhas por ventos de diferentes velocidades aplicados por 15 minutos por meio de um turboatomizador".

Na página 54 , onde está escrito " $20 \mathrm{~m} / \mathrm{s}$, leia-se " $21 \mathrm{~m} / \mathrm{s} "$. 


\section{DADOS CURRICULARES DO AUTOR}

Cícero Alexandre Leite, nascido em 13 de março de 1974, em Santo André - SP, é Engenheiro Agrônomo formado pela Escola Superior de Agricultura "Luiz de Queiroz" Universidade de São Paulo, em 1996. Tem publicado trabalhos sobre entomologia e citricultura. Atualmente trabalha na iniciativa privada, na área de Entomologia Agrícola. 


\section{DEDICATÓRORIA}

Aos meus pais,

José Ferreira Leite Neto e

Maria Luiza Wenceslau Leite

Que me amaram e me ensinaram amar as pessoas, o trabalho e a ciência.

O Autor 


\section{AGRADECIMENTOS}

Ao prof. Dr. Octavio Nakano, pela orientação firme e pela presteza em transmitir gratuitamente, conhecimentos preciosos, os quais propiciaram a realização desse trabalho.

Ao prof. Dr. João Roberto Spotti Lopes, pelas inúmeras sugestões, colaborações e incentivos.

Ao prof. Dr. Sinval Silveira Neto, pelas sugestões e incentivo.

Ao pesquisador Dr. Francisco Laranjeira, pelo apoio prestado e pelas sugestões.

Ao amigo e Tec. Agr. Sr. Augusto César Pinheiro Florim, pelas sugestões de ordem prática que tornaram mais inteligente a montagem dos experimentos.

Ao Departamento de Entomologia da ESALQ-USP, pelo incentivo

Ao Fundo Paulista de Defesa da Citricultura - FUNDECITRUS, pelo apoio financeiro fornecido.

À CAPES, pelo apoio financeiro.

Aos estagiários do setor de controle químico do Departamento de Entomologia, pela ajuda na montagem e condução dos experimentos.

À minha noiva, Eng ${ }^{\mathrm{a}} \mathrm{Agr}^{\mathrm{a}}$ Daniela Terenzi Stuchi, pelo incentivo.

Ao professor Gustavo Angelo Wenceslau, pela revisão do texto. realizado.

A todos que colaboraram, de alguma forma, para que este trabalho fosse 


\section{SUMÁRIO}

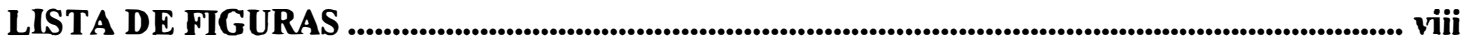

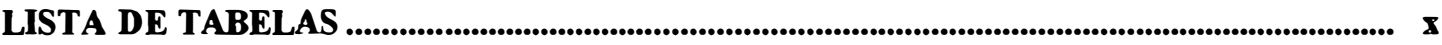

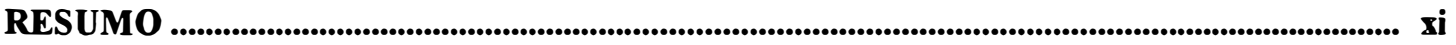

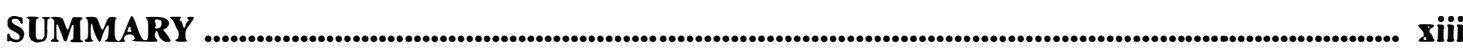

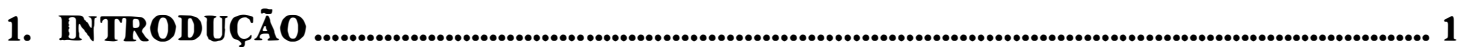

2. REVISÃO DE LITERATURA ............................................................................................... 5

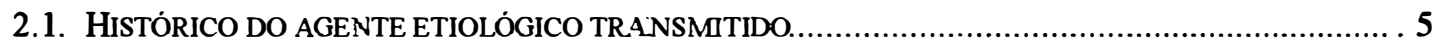

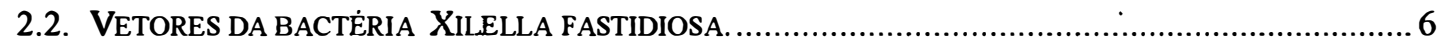

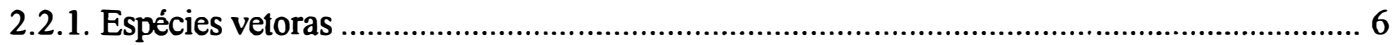

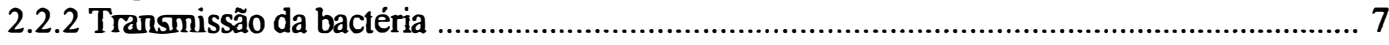

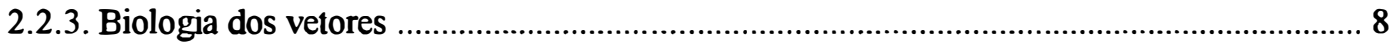

2.3. HOSPEDEIROS8

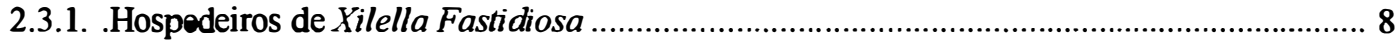

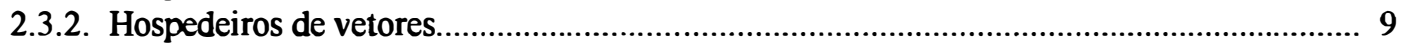

2.4. EPIDEMEOLOGIA DO PATÓGENO E CAPACIDADE DE DISPERSÃO DO VETOR …......................... 10

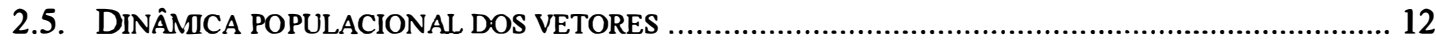

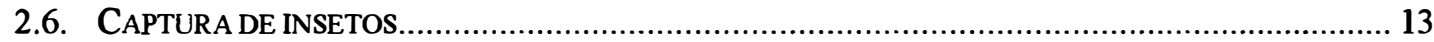

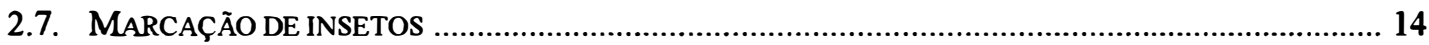

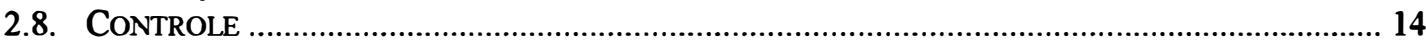

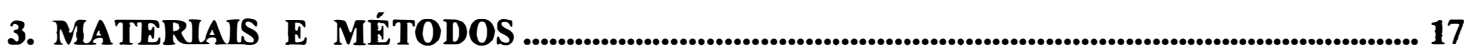

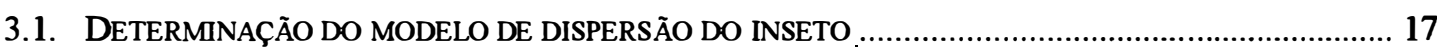

3.1.1. Coleta de cigarrinhas

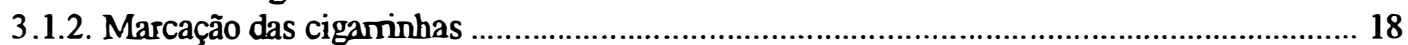

3.1.2.1. Averiguação da mortalidade das cigarrinhas pelos processos de marcaçã o.............................................................................. 18 3.1.2.2. Averiguação da interferência na atividade das cigarrinhas pelos processos de marcação.................................................................................... 18

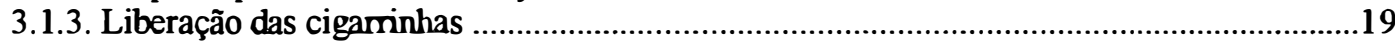

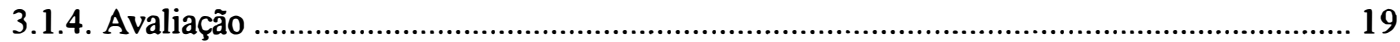

3.2. PERIODO DE ATIVIDADE, DISTRIBUIÇÃO VERTICAL, E PREFERÊNCIA MICROCLIMÁTICA ........... 20

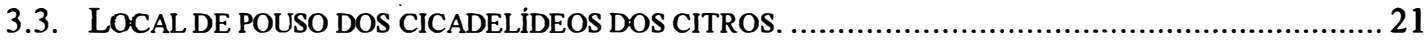

3.4 AÇÃO DO VENTO NA DISPERSÃO DOS CICACADELIDEOS DEOS CITROS. ................................ 22

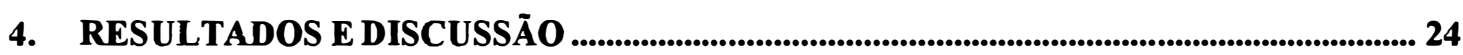

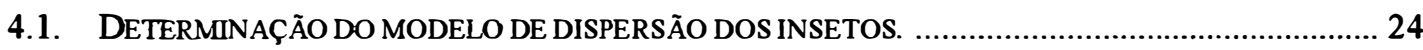

4.2. PERIODO DE ATIVIDADE, LOCAL DE PERMANÊNCIA, PREFERÊNCIA MICROCLIMÁTICA ............. 33

4.3. LOCALE HORÁRIO DE POUSO DOS CICADELIDEOS DOS CITROS ........................................... 46 
4.4. AÇÃO DO VENTO NA DISPERSÃO DE CICADELÍDEOS DOS CITROS. ........................................... 53

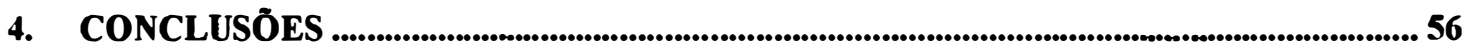

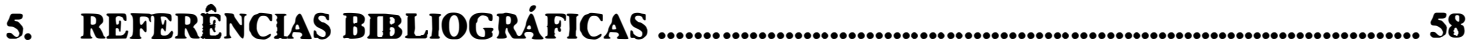




\section{LISTA DE FIGURAS}

Página

1 Regressão linear entre o número de indivíduos de Acrogonia sp recapturados em cada circulo e a distância das armadilhas até o centro de dispersão.

2 Regressão linear entre o número de indivíduos de Acrogonia sp. recapturados em cada circulo e a distância das armadilhas até o centro de dispersão

3 Regressão linear entre o número de indivíduos de Acrogonia sp. recapturados em cada circulo e a distância das armadilhas até o centro de dispersão

4 Localização relativa dos individuos de Acrogônia sp. recapturados, durante 5 dias após a liberação de 107 indivíduos em pomar cítrico em Piracicaba-SP

5 Localização relativa dos indivíduos de Dilobopterus costalimai recapturados, durante 5 dias após a liberaçãode 104 indivíduos em pomar cítrico em Piracicaba-SP

6 Localizaçz̃o relativa dos indivíduos de Oncometopia facialis recapturados, durante 5 dias após a liberação de 97 indivíduos em pomar cítrico em Piracicaba-SP

7 Esquema direções de dispersão das cigarrinhas em um pomar com mata adjacente

8 Distribuição vertical de machos (A) e fềmeas (B) de Acrogonia sp. em diferentes horários do dia em uma laranjeira de 8 anos de idade. Média de 8 repetições

9 Distribuição vertical de machos (A) e fêmeas (B) de D. costalimai em diferentes horários do dia em uma laranjeira de 8 anos de idade. Média de 8 repetições

10 Distribuição vertical de machos(A) e fêmeas (B) de $O$. facialis em diferentes 
horários do dia em uma laranjeira de 8 anos de idade. Média de 8 repetições

11 Órgão vegetais de permanência de machos (A) e fêmeas (B) de $A$. terminalis em diferentes horários do dia em uma laranjeira de 8 anos de idade. Média de 8 repetições

12 Órgão vegetais de permanência de machos (A) e fềmeas (B) de D. costalimai em diferentes horários do dia em uma laranjeira de 8 anos de idade. Média de 8 repetições

13 Órgão vegetais de permanência de machos (A) e fềmeas (B) de $O$. facialis em diferentes horários do dia em uma laranjeira de 8 anos de idade.

Média de 8 repetições

14 Número de indivíduos machos de Acrogonia sp. na periferia da copa correlacionado com a temperatura do ar neste local.

Média de 8 repetições

15 Número de indivíduos machos de Acrogonia sp. na periferia da copa correlacionado com a umidade relativa do ar neste local. Médias de 8 repetições.

16 Correlação entre número de fêmeas de $D$. costalimai e temperatura na parte externa da copa

17 Número de cigarrinhas que pousaram em folhas impregnadas com cola transparente e número de cigarrinhas que pousaram em cartões adesivos amarelo-ouro e amarelo-limão durante 5 dias em um Pomar em CatanduvaSP em Maio de 1998

18 Número total de cigarrinhas que pousaram na cola transparente e número total de cigarrinhas que pousaram em cartões adesivos amarelo-ouro e amarelo-limão, durante 5 dias seguidos em um pomar em Catanduva-SP em Maio de 1998

19 Número de cigarrinhas que pousaram em plantas com cola em diferentes horários do dia. Dados cumulativos de 5 dias em pomar da região de Catanduva-SP em Maio de 1998

20 Número de cigarrinhas que pousaram em cartões adesivos amarelo-ouro em diferentes horários do dia. Dados cumulativos de 5 dias em pomar da região de Catanduva-SP em Maio de 1998

21 Número de cigarrinhas que pousaram em cartões adesivos amarelo-limão em diferentes horários do dia. Dados cumulativos de 5 dias em pomar da região de Catanduva-SP em Maio de 1998 


\section{LISTA DE TABELAS}

Página

1 Número de Acrogonia sp. recapturadas por círculo de armadilhas no período de 6 a 10 de setembro de 1988 a partir da liberação de 108 indivíduos em pomar cítrico em Piracicaba-SP

2 Número de Dilobopterus costalimai recapturadas por círculo de armadilhas no período de 15 a 19 de setembro a partir da liberação de 104 indivíduos em pomar cítrico em Piracicaba-SP

3 Número de Oncometopia facialis recapturadas por círculo de armadilhas no período de 15 a 19 de setembro a partir da liberação de 97 indivíduos em pomar cítrico em Piracicaba-SP

4 Número de cigarrinhas mortas após a marcação com esmalte em 8 Oncometopia facialis e com pó fluorescente em 8 Acrogonia sp. e 8 Dilobopterus costalimai

5 Número de cigarrinhas que foram para o lado iluminado da gaiola após a marcação com esmalte em 8 Oncometopia facialis e com pó fluorescente em 8 Acrogonia sp. e 8 Dilobopterus costalimai

6 Número de indivíduos de Oncometopia facialis retirados das folhas por ventos de diferentes velocidades 


\title{
ASPECTOS DA DISPERSÃO DE TRÊS ESPÉCIES DE CICADELÍDEOS (HEMIPTERA:CICADELLIDAE) DOS CITROS
}

\author{
Autor: CÍCERO ALEXANDRE LEITE \\ Orientador: Prof. OCTAVIO NAKANO
}

\section{RESUMO}

O objetivo do trabalho foi estudar aspectos de dispersão e mobilidade dos principais cicadelídeos transmissores de Xylella fastidiosa às plantas cítricas. Estudouse a dispersão de Acrogonia sp., Dilobopterus costalimai e Oncometopia facialis, a distribuição vertical ao longo do dia, os órgãos vegetais de permanência desses insetos, o local e horário de pouso, bem como a ação do vento sobre o deslocamento de $O$. facialis. Para se estudar a dispersão das cigarrinhas distribuíram-se em um pomar, armadilhas em círculos concêntricos eqüidistantes entre si de 7,5m. Liberou-se cigarrinhas marcadas e anotou-se os dados de posição em 7 dias de avaliação. $O$. facialis e Acrogonia sp. dispersaram-se $37,5 \mathrm{~m}$ e $D$. costalimai permaneceu sendo capturada por apenas 3 dias e dispersou-se $22,5 \mathrm{~m}$. A fim de estudar a distribuição vertical das cigarrinhas, soltaram-se 8 casais de cada uma das espécies citadas dentro de uma gaiola que envolvia toda uma planta cítrica. Foram feitas várias avaliações da posição dos insetos na planta ao longo do dia. Este experimento foi repetido 8 vezes. Notou-se um movimento horizontal de Acrogonia sp. e D. costalimai em função da 
mudança microclimática diária. A maioria desses insetos se distribuiram nos dois terços superiores da planta. $O$. facialis se distribui melhor por toda a copa da árvore, inclusive, com insetos na parte inferior da copa. Avaliou-se o local e horário de pouso dos cicadelídeos de um pomar através de três métodos: com uso de cartões adesivos amarelo-ouro, amarelo limão e com aplicação de película colante e transparente sobre as folhas. As três espécies estudadas preferiram pousar nos terços superior e médio da planta em todos os horários avaliados. Não se observou maior número de pousos em quaisquer dos faces cardeais da planta em todos os horários de avaliação. Com um turboatomizador, aplicaram-se ventos de diferentes velocidades a grupos de $O$. facialis acomodados em planta cítrica situada numa extremidade de uma gaiola, a qual possui, na outra extremidade uma fonte de iluminação e outra planta cítrica. Em 15 minutos, $50 \%$ das cigarrinhas foram, espontaneamente, para a outra extremidade da gaiola, e com a aplicação de vento foi necessário aplicar uma velocidade de $12 \mathrm{~m} / \mathrm{s}$, para retirar a mesma quantidade de insetos, o que sugere que o vento faz as cigarrinhas se fixarem mais às plantas. Foi necessário um vento de $20 \mathrm{Km} / \mathrm{h}$ para se retirar todas as cigarrinhas de uma planta o que indica que esses insetos dispersam-se através do seu próprio vôo ativo e não aproveitam as correntes de vento para se dispersar em um pomar. 


\title{
ASPECTS OF DISPERSAL OF THREE SPECIES CICADELLIDAE (HEMIPTERA:CICADELLIDAE) OF CITRUS
}

\author{
Author: CÍCERO ALEXANDRE LEITE \\ Adviser: Prof. OCTAVIO NAKANO
}

\section{SUMMARY}

The goal of this work was study the dispersal and mobility of the main cicadellids vectors of Xilella fastidiosa in the citric plants. Study the dispersal of Acrogonia sp., Dilobopterus costalimai and Oncometopia facialis, the vertical distribution along the day, the vegetal parts containig this insects, the place and hour of resting-place of. this sharpshooters, and also, the wind action in dispersal of $O$. facialis. For study the dispersal, it was spread yellow sticker traps in concentric circles and equidistants itself $7,5 \mathrm{~m}$. The maked insects was set free and it was noted the position datas in 7 days of evaluetions. O. facialis and Acrogonia sp had dispersal of $37,5 \mathrm{~m}$. and $D$. costalimai stayed been captured along only 3 days and had dispersal of $22,5 \mathrm{~m}$. For study the vertical distribuition of sharpshooters, it was liberated 8 mates of each mentioned specie within a cage, which wraped whole one citric tree. It was made several evaluations of the insects position in the plant during the day. This experiment 
was repited 8 times. It was noted a horizontal moviment of Acrogonia sp and $D$. costalimai in function of the daily microclimatics changes. The most of this sharpshooters spreaded on the two up-parts of the tree. O. facialis spreaded in every parts of the plant, including insects on the low part. It was evaluated the place and hour of. resting-place of cicadellids from a orchard by three methods: gold-yellow sticker trap, lemon-yellow sticker trap, and aplication of sticker film on the leaves. The three studied species preffered to set on the canopy parts of the plant in all evaluated hours. It was not observated some grater resting-place number in any cardeal face of the tree in all evaluated hours. With a turboatomizer, it was applied winds with diferents speeds in $O$. facialis groups wich was in a plant in na extremity of a cage. This cage had, in the outher extrmity, other citric plant and one light font. In $15 \mathrm{~min}$., $50 \%$ of sharpshooters went out the plant flighting to other extremity. With wind, was necessary a $12 \mathrm{~m} / \mathrm{s}$ speed to take out the same quantity of insects, what sugest the wind induce the insects fixation in the plant. It was necessary a wind with $20 \mathrm{~m} / \mathrm{s}$ velocity for take out the sharpshooters of the plant, wich show that these insects make its dispersal by itself flyght and not profit by the winds for spreed itself in an orchard. 


\section{INTRODUÇÃO}

O estado de São Paulo é o maior produtor individual de citros do mundo (Neves 1992). Ele é responsável por cerca $70 \%$ da produção brasileira, com 400 milhões de caixas de 40,8 $\mathrm{Kg}$ (Abecitrus, 1999), A citricultura está entre as cinco principais explorações agrícolas do estado (Amaro \& Maia, 1994). E atualmente vem enfrentando vários problemas fitossanitários, que estão aumentando nos últimos anos, comprometendo os programas de manejo integrado de pragas dos citros, que estavam indo bem até o surgimento da Clorose Variegada dos Citros (CVC) (Gravena, 1998)

Em 1987, a doença foi constatada em municípios do noroeste paulista afetando plantas independentemente do porta-enxerto utilizado (Rossetti \& de Negri, 1990). Mais recentemente, a doença está presente em quase todo o estado chegando a inviabilizar o plantio de citros nos municípios muito afetados. Além do estado de São Paulo está presente em todo o Centro-Sul (Tubelis et al., 1993), e no Nordeste (Laranjeira et al., 1996).

Rossetti \& de Negri (1990) relataram os sintomas que podem surgir nas folhas: há o surgimento de manchas cloróticas internervais, as quais são pequenas no início mas evoluem até o total amarelecimento da superfície superior da folha. A essas cloroses correspondem manchas de coloração entre o vermelho e o marrom. As manchas podem ser puntuais ou difusas, não sendo necróticas. Há uma tendência de frutificação em "pencas" e os frutos tornam-se duros e pequenos em relação aos 
normais, além de adquirir a coloração típica de fruto maduro, e permanecer com a casca fina, facilitando as queimaduras de sol (Palazzo \& Carvalho, 1992). Laranjeira \& Palazzo (1994), mostraram que há um aumento na acidez e no teor de sólidos solúveis (Brix), parecendo ser um efeito, apenas, da concentração. Por conseqüência, a produção total de sólidos solúveis é menor, o que prejudica a produção de suco, além da comercialização de frutos in natura. Segundo Palazzo \& Carvalho (1993), as plantas aparentemente sadias, produziram 30 a $35 \%$ a mais que as doentes. Todas as variedades de laranja doce Citrus sinensis L. Osbeck são afetadas pela doença, independentemente do porta-enxerto. Os sintomas de Amarelinho podem ser observados em plantas de viveiro e em pomares, em formação ou produção. Nas plantas com idade superior a 15 anos os sintomas são mais localizados e não afetam a planta toda (Beretta et al. 1992).

O agente etiológico da doença é uma bactéria associada ao xilema, denominada Xylella fastidiosa (Wells et al.,1987; Leite Junior \& Leite, 1991; Beretta, 1992). Chang et al.(1993) cumpriram os postulados de Koch e Lee et al. (1993) confirmaram. Machado et al. (1992) constataram que essa bactéria pode se desenvolver no xilema das plantas cítricas, e entupir esses vasos.

A bactéria causa doenças em outras culturas, como as da videira, amêndoa, alfafa, pêssego, pêra, cereja e outras. Em todas a transmissão é feita por insetos vetores, que têm a característica de se alimentar em vasos de xilema (Purcell, 1980, 1982, 1989; Hopkins, 1989).

Roberto et al.(1996), Lopes et al.(1996) relataram Dilobopterus costalimai, Acrogonia sp. e Oncometopia facialis. como sendo transmissoras de $X$. fastidiosa a citros. Tebar et al.(1994) detectaram a bactéria por meio de testes serológicos, nas cabeças de outras espécies de cigarrinhas, o que sugere que pode haver outras espécies transmissoras. Jacomino et al. (1993), Rossetti et al.(1995) relatam que a doença também pode ser transmitida através de enxertia, sendo portanto as únicas formas possiveis de transmissão até então conhecidas, a enxertia de material vegetal infectado ou a transmissão pelas cigarrinhas encontradas nos citros. 
Conhecendo-se o agente etiológico, os prejuízos da doença e identificados seus principais vetores, a comunidade científica objetiva conhecimentos mais detalhados sobre as relações desses cicadelídeos vetores com os hospedeiros e o patógeno. Este trabalho foi concebido em função da necessidade de se conhecer mais sobre aspectos ecológicos dos vetores, mais precisamente, referentes à dispersão Acrogonia sp. Dilobopterus costalimai e Oncometopia facialis.

A importância de se estudar os aspectos de dispersão dos cicadelídeos, está no fato de esses insetos serem vetores de uma das principais doenças dos citros.

Conhecendo as velocidades com que se deslocam em um pomar e a influência dos ventos sobre a dispersão, bem como, os locais e horários de pouso, pode-se contrastar os dados com os estudos sobre a epidemeologia do patógeno e concluir se há ou não relação entre a dispersão do vetor e a propagação da doença. Em havendo tal relação, e sendo ela significativa, poder-se-ia cogitar o desenvolvimento de outros trabalhos a fim de se elaborar um novo método de controle do vetor a partir da informação das localizações das plantas com sintomas, ou pelo subsidiar estudos posteriores que objetivam racionalizar as pulverizações de pesticidas para controle desses vetores.

Experimentos sobre os locais de permanência na planta, os horários de saída e de pouso, e a verificação da influência de fatores climáticos sobre a mobilidade dos cicadelídeos dos citros podem esclarecer pontos primordiais para se reformular os métodos atuais de inspeção de pomares. Através deste trabalho detectamos onde um cicadelídeo pousa quando se desloca de uma planta para outra em um pomar, ou seja, onde há a maior probabilidade de ocorrerem as primeiras picadas que transmitiriam Xylella fastidiosa. Estudando os locais de permanência das cigarrinhas na planta em diferentes horários do dia, pode-se caracterizar os seus movimentos dentro de uma única planta e verificar se pode transmitir a bactéria não só nas partes novas e altas das plantas mas em outras partes mais interioranas e mais nas bases dos ramos.

Os objetivos específicos desta obra são: (1) conhecer o modelo de dispersão dos cicadelídeos dos citros em um pomar cítrico, (2) conhecer os locais e os horários 
preferidos de pouso desses insetos; (3) verificar a distribuição dos mesmos na planta cítrica; (4) investigar a influência do vento no deslocamento das cigarrinhas. 


\section{REVISÃO DE LITERATURA}

\subsection{Histórico do agente etiológico transmitido}

O agente etiológico da clorose variegada dos citros (CVC) tem sido constatado como sendo a bactéria Xylella fastidiosa a qual causa doenças em culturas perenes e anuais. Como exemplo de culturas afetadas economicamente devido a esse patógeno tem-se: Vittis vinifera L. (Goheen et al., 1973; Hopkins \& Mollenhauer, 1973; Raju \&Wells, 1986; Hopkins, 1989.), pêssego Prunus persicae (L.) Batsch (Hopkins \& Mollenhauer, 1973), ameixa Peunus salicina (Kitajima et al. 1975; French \& Kitajima,1978), amêndoa Prunus amigdalus Batsch (Mircetich et al.,1976) amora Morus rubra L., carvalho Quercus rubra L., vinca Vinca minor L.(Sherald et al. 1983, Hearon et al., 1986 citados por Hopkins, 1989); citros Citrus sinensis L. Osbeck (Rossetti \& de Negri, 1990; Lee et al., 1991), cafeeiro Coffea arabica L. (Paradella et al. 1995; Lima et al., 1996).alfafa Medicago sativa L. (Goheen et al. 1973).

Esta bactéria tem sido constatada causando problemas em citros na Argentina e no Brasil. Na Argentina a doença foi relatada, pela primeira vez, com o nome de "pecosita" ou "falsa mancha grasienta" na região de Missiones (Contreras, 1992). No Brasil, a doença foi primeiramente observada em 1987 no noroeste paulista e foi chamada de Amarelinho ou Clorose Variegada dos Citros (CVC) (Rossetti \& de Negri, 1990). Chang et al.(1993) cumpriram os postulados de Koch e Lee et al. 
(1993) confirmaram o fechamento desses postulados comprovando que o agente causal dessa bacteriose é realmente a $X$. fastidiosa.

\subsection{Vetores da bactéria Xylella fastidiosa}

\subsubsection{Espécies vetoras}

Todos os vetores de Xylella fastidiosa em quaisquer culturas, têm a característica de se alimentar nos vasos de xilema (Purcell, 1980, 1982, 1989; Hopkins, 1989). Estes insetos são cigarrinhas que se alimentam do xilema das plantas e pertencem às famílias Cercopidae e Cicadelidae, subfamília Cicadellinae (Turner \& Pollard, 1959; Purcell \& Frazier, 1985).

Em citros, Coll et al. (1996), trabalhando com levantamento populacional das espécies da Argentina, cita que as cigarrinhas potencialmente transmissoras de CVC mais comuns nesse país foram: Molomea consolita Schöder, Oncometopia facialis (Signoret), Acrogonia sp. Scaphytopius boliviannus (Oman), Sonesimia grossa (Signoret) e Ceresa ustulata Fairmaire. As espécies Bucephalogonia xantopis (Berg), Macugonalia cavifrons (Stal), Acrogonia flaveoloides Young, e Scaphytopius bolivianmus(Oman) foram encontradas somente nas laranjeiras. Yamamoto \& Gravena (1998) realizaram um levantamento de agosto de 1993 a julho de 1995 em 16 propriedades da região de Catanduva, Monte Azul Paulista e Barretos. Estes autores encontraram 58 espécies de Cicadellidade, pertencentes às subfamílias Cicadellinae, Acinopterinae, Agalinae, Coelidinae, Deltocephalinae, Gyponinae, Hecalinae, Ledrinae, Macrostelinae, Typhlocybinae e Xestocephalinae.

Segundo Paiva et al.(1996), existem mais de setenta espécies de cigarrinhas associadas a citrus no estado de São Paulo, porém, a maioria se alimenta do líquido

do mesofilo foliar ou do floema, que é muito rico em nutrientes. Poucas são as que se especializaram em se alimentar do xilema das plantas. Segundo este autor, pode-se dividir as cigarrinhas de xilema de citros em dois grupos: o primeiro formado por 
espécies que ocorrem quase que exclusivamente em citros: Acrogonia sp., $D$. costalimai, e Oncometopia; o segundo grupo é formado por espécies que ocorrem mais nas plantas invasoras, mas que podem ser encontadas com certa freqüência nos citros: Bucephalogonia xanthopis e Macugonalia leucomelas.

\subsubsection{Transmissão da bactéria}

Purcell $(1980,1982,1989)$ afirma que todas as espécies da subfamília Cicadellinae e da família Cercopidae são potenciais transmissoras da bactéria, pois se alimentam do xilema. Lopes (1996) afirma que até mesmo as cigarras pertencentes à família Cicadidae apresentam possibilidades de serem transmissoras, pois se alimentam dos vasos lenhosos.

Segundo Purcell (1994), as cigarrinhas adquirem o patógeno ao se alimentarem de líquido xilemático previamente infectado com Xylella fastidiosa, a qual fica aderida ao aparelho bucal do inseto, podendo ser, por ele, inoculada em uma planta sadia durante $o$ ato de alimentação.

Purcell (1982) afirma que a transmissão por vetores pode ser dividida nas seguintes fases sequenciadas: aquisição; latência; e inoculação. Todos os estádios metabólicos das cigarrinhas podem transmitir a bactéria para as plantas, porém as ninfas perdem a capacidade de transmissão a cada ecdise, sendo necessária uma nova aquisição da bactéria para que possam transmiti-las novamente. (Purcell \& Finlay, 1979). Com a troca de pele, há também a troca da extremidade do aparelho bucal, parte esta, que contém as bactérias. Desse modo as cigarrinhas perdem a infectividade. Como os adultos não sofrem ecdises uma vez infectados podem transmitir a bactéria até o fim de suas vidas. Hill \& Purcell (1995) fizeram um experimento com um cicadelídeo que não ataca citros. Eles mostraram uma curva de eficiência de transmissão por adultos, na qual a eficiência é de $50 \%$ no início, subindo para 90 e voltando a cair no final da vida do inseto. Isto sugere que possa haver uma curva semelhante para os vetores de $X$. Fastidiosa em citros. Segundo Purcell \& Finlay (1979) a perda de infectividade das cigarrinhas $G$. artropuncta após a muda, a 
ausência do período latente e o curto periodo de aquisição e transmissão sugerem que a bactéria não circula nestas cigarrinhas.

\subsubsection{Biologia dos vetores}

As principais espécies comprovadamente vetoras mais comumente encontradas em citros são Dilobopterus costalimai Young,1977, Acrogonia sp. e Oncometopia sp. (Signoret,1854). Segundo Lima (1995), a primeira prefere se alimentar de ramos jovens e coloca os ovos isolados dentro do mesofilo foliar desse tipo de folhas, próximo a suas nervuras. Oncometopia sp. se alimenta de ramos maduros dos citros e seus ovos tem sido encontrados nas páginas inferiores das plantas em número de 10 a 20 recobertos ou não por cerosidade branca. $A$. terminalis geralmente se alimenta sobre folhas novas e faz postura externamente em duas camadas totalizando 15 a 25 ovos cobertos com cera (Paiva et al.,1996). As larvas nascem entre 7 a 14 dias e elas passam a sugar a seiva em algumas horas, transformando-se em adultos após 4 ou 5 ecdises, o que pode levar de 40 a 80 dias. Os adultos vivem meses (Lima et al. 1995).

\subsection{Hospedeiros}

\subsubsection{Hospedeiros de Xylella fastidiosa}

As plantas hospedeiras da bactéria $X$. fastidiosa pertencentes ao gênero citrus são: as laranjas doces, Citrus sinensis Osb., tangerinas ,Citrus reticulata Blanco, Tangores Citrus sinensis Osb x Citrus reticulata Blanco, tangelos Citrus reticulata Blanco x Citrus paradise Macf.,e lima ácida Tahiti Citrus latifolia Tan. (Laranjeira et al., 1996)., sendo que as tangerinas e seus híbridos como tangelos e tangores apesar de mostrar sintomas de CVC, são bem menores que em laranjas doces. Destas, as 
variedades que tem se mostrado mais resistentes são a Westin e Ovale. (Pompeu Junior et al. 1994; Laranjeira, et al. 1996a).

No Brasil, Kitajima et al. (1981) encontraram a bactéria em ameixeira, e Harakava et al.(1994) e Travensolo \& Leite Junior (1996) encontraram em diversas plantas daninhas como a guanxuma e o capim pé-de-galinha. Segundo Hopkins \& Adlerz (1988) existem muitas plantas que hospedam a bactéria e algumas delas podem hospedar também cigarrinhas vetoras do patógeno. Paradela Filho et al. (1995) encontraram a bactéria em cafeeiro e Lima et al.(1996) encontraram a bactéria em folhas, ramos e raízes de cafeeiros do sul do estado de São Paulo, no município de Capela do Alto, no norte do estado, no município de Colina, e na região cafeeira de Minas Gerais, no município de Guaxupé. Segundo estes autores, a bactéria Xylella fastidiosa produz sintomas de escaldadura de folhas, e por isso eles sugerem que a doença seja chamada de "Requeima do Cafeeiro". Uma vez que, no estado de São Paulo, os parques cafeícolas estão situados, literalmente, do lado de pomares cítricos, um cafezal infectado pode tornar-se uma importante fonte de inóculo de bactérias $X$. fastidiosa.

\subsubsection{Hospedeiros dos vetores}

Os cicadelídeos vetores dos citros, também já foram encontrados em cafezais. A migração contínua de vetores de um agroecossistema cafezal para um laranjal e vice-versa pode significar a constante infecção de um pomar ou de um cafezal. É possivel que os cicadelídeos dos citros, realmente prefiram pousar sempre em plantas arbustivas, saindo de uma laranjeira, para pousar em outra ou para pousar em um cafeeiro, ao invés de pousar e permanecer em plantas herbáceas. Esta hipótese é suportada por um experimento de Lopes et al. (1997), que trabalhando em casa de vegetação, realizaram um experimento que lhes permitiram concluir que as plantas arbóreas ou arbustivas são preferidas às herbáceas. Estes autores listam como plantas preferidas das cigarrinhas: Amaranthus viridis, Catharanthus roseus, Citrus sinensis, Coffea arabica, Lantana camara, Mimosa sp e Sorghum halepense para Dilobopterus 
costalimai e A. viridis, C. sinensis, Mimosa, sp. e S. halepense para Oncometopia sp. A preferência por cafeeiro e citros faz presumir que durante a migração de uma cigarrinha dificilmente ela pousaria em outra planta. Outro fato que reforça esta hipótese é o experimento de Gravena et al. (1998b) que realizaram um extenso trabalho que provou que o controle das ervas daninhas existentes nos pomares não influenciou as densidades das cigarrinhas vetoras da CVC em pomares de citros.

\subsection{Epidemeologia do patógeno e capacidade de dispersão do vetor}

Estudos ecológicos dos vetores em paralelo com dados epidemiológicos da doença são de fundamental importância para se entender a progressão da doença em um pomar. Alguns autores que fizeram conjecturas a respeito do assunto foram Gottwald et al. (1993). Eles estudaram a progressão da CVC e verificaram que a evolução temporal da doença segue o modelo de Gompertz. Eles constataram, ainda, que, o arranjo das plantas doentes bem como a dinâmica espacial sugere associação com vetores de limitada dispersão aérea. Palazzo \& Carvalho, 1992., trabalhando com a variedade Natal no município de Colina-SP. encontraram um aumento na incidência e na severidade dos sintomas em folhas nos meses de primavera e verão, coincidindo com épocas de elevada temperatura e umidade relativa do ar. Em seu experimento, no mês de março observou-se o máximo de incidência, com $35,7 \%$ de folhas lesadas e também, o máximo de severidade, com $34,8 \%$ de área foliar atacada. A partir de Abril, os sintomas começaram a diminuir chegando a incidência de $1 \%$ no mês de Setembro. Segundo Laranjeira et al. (1998), há épocas com maiores e menores proporções de plantas afetadas com CVC. Tais proporções foram obtidas pelo autor, dividindo-se o número de plantas afetadas pelo número total de plantas de um talhão. Eles ainda calcularam as velocidades de progresso da CVC nas quatro estações do ano, chegando à conclusão que as maiores velocidades de progresso se deram nos meses de primavera e verão, e foram cerca de cinco vezes maiores que as velocidades no inverno e outono. Teoricamente, a porcentagem de plantas infectadas por um 
patógeno transmitido por vetores depende: do número de insetos vetores; da eficiência de transmissão do patógeno; e do movimento do vetor de planta para planta (Purcell, 1982).

As fontes de inóculo de patógeno, são de fundamental importância para a progressão da doença CVC. Dois aspectos devem ser considerados: o volume de inóculo e a proximidade com a área onde será transmitida a doença. Quanto às potenciais fontes de inóculo da $X$. fastidiosa, Lopes et al. (1998) afirmam que há possibilidade da bactéria ser transmitida de citros para café e vice-e-versa, uma vez que as mesmas espécies de vetores existentes em citros foram encontradas em altas populações em cafeeiros, na região de Bebedouro-SP. No entanto, Laranjeira (1997) constatou que as maiores fontes de inóculos do patógeno para os pomares cítricos são os pomares velhos infectados, vizinhos dos recém plantados. Este autor ainda afirma que as matas podem ser fontes de inóculo. Este fato pode ser mais uma indicação de que $D$. costalimai, $A$. terminalis e $O$. facialis dispersam se pouco, ou não tenham capacidade de migrar a grandes distâncias. Laranjeira et al. (1998) verificaram que não houve influência do vento, ou da passagem de máquinas no pomar na disseminação da doença. Segundo Taylor (1989), movimentos de longa distância para pequenos insetos como pequenas cigarrinhas e pulgões dependem inteiramente do vento, porém, em se tratando de vôos de curta distância, Taylor (1974) citado por Lopes et al. (1995) afirmam que o melhor horário para vôos não migratórios é ao cair da tarde, devido serem mínimas as chances de algum vento ocorrer para deslocar os insetos.

Em se tratando, ainda, de capacidade de movimentação de cicadelídeos vetores Purcell \& Frazier (1985) relataram que as cigarrinhas se dispersaram quando os hospedeiros de procriação se encontram em crescimento e afirmam que os insetos são atraídos por luz, logo após o por do sol, tendo em vista que eles verificaram a maior parte dos vôos neste horário. Hunt (1988) citado por Lopes et al.(1995), trabalhando com Graminella nigrifons, um cicadelídeo vetor de virose ao milho, também constatou que machos e fềmeas virgens dessa espécie apresentam atividade de vôo, sobre o topo das plantas de milho, ao cair da tarde. Lopes et al. (1995) 
concluiram que o movimento vertical de adultos de $G$. nigrifons depende da intensidade de luz e do fotoperíodo e varia com a idade e sexo desses cicadelídeos. Os cicadelídeos dos citros também podem apresentar possibilidades de responderem a fotoperíodo, e de se deslocarem vertical ou horizontalmente na planta, diariamente, inclusive de modo diferenciado entre os sexos em função de estímulos ambientais.

É importante considerar a movimentação das cigarrinhas dos citros ao longo do tempo. O movimento desses insetos no decorrer do ano pode ser atribuído às condições climáticas e à população de inimigos naturais, que em determinadas épocas, podem levar o ambiente a ser tão inóspito a ponto das cigarrinhas efetuarem migrações para áreas de refúgio. Segundo Paiva et al.(1996), a partir de agosto/setembro há um decréscimo na população das cigarrinhas, provavelmente devido à migração e ao ataque de inimigos naturais como himenópteros parasitóides de ovos ou por predadores de ninfas como as aranhas. Almeida et al.(1997) constataram uma considerável correlação, quando os dados populacionais de cigarrinhas adultas foram relacionados com variáveis climáticas de dois a três meses anteriores, sugerindo que o clima pode influir no desenvolvimento das ninfas. Estes autores ainda afirmam que a distribuição de $D$. costalimai e $A$. terminalis é agregada, e que esta última fica mais concentrada nas plantas cítricas próximas a mata.

\subsection{Dinâmica populacional dos vetores}

Nos meses de primavera e verão, Paiva et al. (1996), Yamamoto (1998), encontraram os picos de flutuação populacional dos insetos vetores da doença. Os experimentos de Taylor (1985) e Martinson et al. (1994) sugerem que outros cicadelídeos apresentam alta capacidade de dispersão, colonizando vários habitats diferentes durante sua vida, ou de uma geração para a seguinte. Estas cigarrinhas mostram hábito alimentar diferente das espécies vetoras de $X$. fastidiosa em citros, chamadas cigarrinhas de xilema, e talvez por isso, seu comportamento de dispersão seja diferente. Novotny (1995) realizou um experimento com delphacideos e 
cicadelideos onde concluiu que as diferenças entre as intensidades de distúrbios entre os vários habitas refletiu-se na biologia e dispersão dos insetos. As cigarrinhas que são hospedadas por plantas ruderais se dispersam mais e em um maior número de hospedeiros, bem como apresentam maior número de gerações por ano do que as que se hospedam em plantas competitivas. Como citros é considerada uma planta ruderal, pode-se esperar que, realmente, os cicadelídeos que nela vivem sejam de baixa capacidade de dispersão.

Bevenga et al. (1998) contribuiram para o conhecimento da capacidade de movimento do inseto realizando um trabalho para averiguar a capacidade de vôo das cigarrinhas dos citros chegando às seguintes conclusões: Acrogonia gracilis e Dilobopterus costalimai apresentaram distância e velocidade média de vôo de 30 metros e $9,0 \mathrm{Km} / \mathrm{h}$, respectivamente; Oncometopia facialis voou cerca de 45 metros a $15 \mathrm{~km} / \mathrm{hora}$.

\subsection{Captura de insetos para estudos ecológicos}

Quanto à forma de captura desses insetos, para a realização de estudos ecológicos e de levantamentos populacionais Purcell \& Elkinton (1980) trabalhando com cigarrinhas de cerejeira; Timmer et al, com Oncometopia nigricans em citros, bem como Gravena et al.(1998a) e Roberto et al. (1997), trabalhando com homópteros dos citros chegaram à conclusão de que a armadilha adesiva de atração por cor amarela foi o melhor método para se fazer levantamento desses insetos. Roberto et al. (1996) encontraram mais cigarrinhas nas armadilhas da face norte. Timmer et al. (1982), também encontrou este resultado para a espécie $O$. nigricans, porém este autor trabalhou em pomares no hemisfério norte, na Flórida-USA. Gravena et al. (1998a) verificaram ainda que, os melhores horários de amostragem feitas por este tipo de armadilha foram: em torno das 12:00 horas em Ararquara-SP e entre 14 e 16 horas em Bebedouro-SP. As diferenças climáticas entre as duas localidades possivelmente interferiram no comportamento desses insetos, o que vem a ser refletido na diferença 
de horários de captura. De fato, a armadilha amarela é satisfatória para monitoramentos desses insetos, porém não se mostra como ideal para estudos com relação a determinação de nichos-ecológicos ou à verificação de preferências microclimáticas, pelo fato de se consistir em uma armadilha ativa, ou seja, de atrair os insetos, interferindo assim no seu comportamento espontâneo.

\subsection{Marcação de Insetos}

Estudos de bioecologia requerem observações constantes da atuação do inseto em seu habitat ou mais amplamente, no ambiente. Estas observações devem ser feitas no campo, utilizando-se de marcadores. Segundo Silveira Neto et al. (1976), a marcação é um método relativamente simples de ser empregado, no entanto, as substâncias usadas na marcação bem como a técnica utilizada devem atender certos pré-requisitos básicos citados em sua obra. Um deles é a não interferência da marca no comportamento do inseto. Segundo Southwood (1987) a natureza química das substâncias usadas para a marcação de insetos e a escolha do método dependerá do inseto a ser estudado e do objetivo que se pretende alcançar.

Larsen \& Whalon (1988) realizaram um experimento com Paraphlepsius irroratus (Hemiptera: Cicadellidae) e verificaram que a marcação com pó fluoresente parece não influir na atividade de vôo e na sobrevivência. Botemberg \& Litsinger (1989), trabalhando com cigarrinha verde do arroz - Nephotettix virescens afirmam que o pó fluorescente com alguma propriedade adesiva e com baixa solubilidade em água apresentou-se muito satisfatório para a realização de experimentos de dispersão.

\subsection{Controle}

Uma vez que até então, não há variedades comerciais resistentes e os programas de melhoramento genético são extensos, o controle da CVC, tem sido feito pelos citricultores através de tratos culturais e através do controle do vetor. Dentre as medidas culturais hoje usadas estão: a aquisição de mudas sadias; a poda de 
ramos com sintomas em plantas velhas; erradicação de plantas com folhas sintomáticas com até 1,5 anos, ou de plantas com frutos miúdos com até 4 anos de idade (Garcia Junior, 1995) De fato, Amaral et al. (1994) realizaram um experimento, no qual fizeram a poda drástica de ramos de borbulheiras contaminadas com 10 anos de idade no mês de janeiro de 1994, depois de cinco meses da poda, verificaram que as plantas testemunhas permaneceram com sintomas de CVC e as plantas podadas estavam vigorosas, exibindo grande produção de ramos e folhas intensamente verdes e sem alterações morfológicas associadas à CVC. Com relação ao controle do vetor, Adlers et al. (1989), pesquisando a evolução da doença "Blight", na Flórida, nos Estados Unidos da América, realizaram um experimento, no qual compararam uma área tratada com pulverizações suplementares para controle de Oncometopia nigricans e Homaladisca coagulata, e uma área onde eram feitas pulverizações normais. $\mathbf{O}$ experimento foi feito para laranjeiras Valência e Pêra. Eles compararam o número acumulado de cigarrinhas em 6 anos e a evolução da doença nesse período. Constataram, através do monitoramento com armadilhas amarelas adesivas, que houve menor população de cigarrinhas, tanto nas áreas de cultivar Valência como de Pêra tratadas com pulverizações suplementares para controle desses insetos. Nessas áreas, houveram significativas reduções da doença "Blight" em relação às áreas sem pulverizações suplementares. Esses autores afirmam que esses dados suportam a hipótese que a doença é causado por $X$. fastidiosa, a qual é transmitida por vetores, e concluíram que apesar de o controle do vetor não parar a distribuição da doença, ela a reduziu o bastante para o estudo garantir como um método prático de controle, pois chega a salvar, em média 3,7 árvores/ha/ano, as quais valem bem mais que o custo do tratamento suplementar. Garcia Junior et al. (1995) afirmam que as cigarrinhas transmissoras de CVC são muito sensíveis a inseticidas fosforados, os quais, segundo este autor, devem ser usados em viveiros e em plantas novas no campo a cada 15 dias na estação chuvosa, quando houver vegetação. Segundo Paiva et al.(1996) as cigarrinhas de xilema de citros têm sido alvo de inspeções especiais em plantas com vegetações novas. Cogitou-se controlar a evolução da CVC, com pulverizações contra os vetores concentradas no tempo, ou 
seja, em determinada estação do ano (Paiva et al. 1996), (Roberto,1997). Gravena (1998), recomenda que com apenas $10 \%$ de plantas infestadas seja feita aplicação de inseticida. Para que se possa evitar a progressão de uma doença em uma cultura perene como o citros é necessário que a eficiência de controle do vetor seja muito alta. Laranjeira et al. (1998b), comentaram sobre a concentração do controle da CVC, no espaço, ou seja, nos focos da doença. Isto não é possível, pois segundo este autor é muito dificil, na prática, delimitar um foco de CVC a partir de uma única planta com sintomas encontrada no pomar. Mesmo encontrando os focos, o controle seria, então, da doença e não dos vetores, uma vez que eles se dispersam com certa velocidade. Para se obter a maior eficiência possível no controle da doença através do monitoramento do vetor, com menor número de aplicações de inseticidas durante o ano, são necessários maiores conhecimentos sobre a localização das cigarrinhas nas plantas, seus hábitos de dispersão, bem como os fatores que influenciam no deslocamento desses cicadelídeos. 


\section{MATERIAIS E MÉTODOS}

\subsection{Determinação do modelo de dispersão do inseto}

Um experimento foi realizado em setembro/outubro de 1998, no pomar experimental da ESALQ-USP em Piracicaba-SP, para cada uma das seguintes espécies: Oncometopia facialis, Acrogonia sp. e Dilobopterus costalimai. No pomar, cuja idade era de 8 anos e cujo espaçamento era $7 \times 8$ metros, foram dispostas armadilhas adesivas amarelas a uma altura de $1,80 \mathrm{~m}$ em relação ao solo, em círculos concêntricos eqüidistantes de 7,5 $( \pm 1 \mathrm{~m})$ entre si. Foram traçados cinco círculos a partir de uma planta onde foi feita a liberação: o menor círculo tinha 6 armadilhas, sendo uma em cada planta. O seguinte tinha 12 armadilhas, o terceiro tinha 24 armadilhas, o quarto tinha $32 \mathrm{e}$ o quinto 48 . A área experimental, portanto, cobriu um raio médio de cerca de 37,5 metros em todas as direções contendo um total de 122 armadilhas, as quais eram de cor amarelo-limão e mediam 7,5x12 cm.

\subsubsection{Coleta de cigarrinhas}

As cigarrinhas foram coletadas em pomares cítricos da região de Limeia-SP e foram acondicionadas em mudas de plantas cítricas com aproximadamente $80 \mathrm{~cm}$ de altura. Estas foram mantidas por 24 horas em sala com temperatura de $25^{\circ} \mathrm{C} \pm 2^{\circ} \mathrm{C}$ e umidade do ar em torno de $70 \%$. 


\subsubsection{Marcação das cigarrinhas}

Foram montados dois experimentos para determinar se os métodos de marcação escolhidos interfeririam na atividade e na mortalidade de cada espécie estudada

\subsubsection{Averiguação da mortalidade das cigarrinhas pelos processos de} marcação.

Para a marcação, os indivíduos de Oncometopia facialis eram presos em uma dobra do filó que envolvia a muda que os hospedavam. Em seguida, levavam um toque de esmalte verde-limão com pincel de poucos pêlos na região do escutelo. $D$. costalimai e Acrogonia sp. foram marcadas com pó fluorescente através de um pincel. $\mathbf{O}$ aprisionamento destas espécies para marcação foi feito da mesma maneira que para Oncometopia.

Utilizou-se 8 cigarrinhas de cada espécie. Cada grupo de 8 foi mantido em uma muda cítrica com $50 \mathrm{~cm}$ de altura, a qual era envolvida por uma tela de filó. Foram mantidas, também 8 cigarrinhas de cada espécie sem marcar para servirem de testemunhas. As mudas contendo as cigarrinhas foram mantidas em sala com umidade em torno de $70 \%$ e temperatura de $24 \pm 2^{\circ} \mathrm{C}$. As avaliações de mortalidade foram feitas aos 15 minutos, uma hora, 24 horas e 48 horas após a marcação.

\subsubsection{Averiguação da interferência na atividade das cigarrinhas pelos processos de marcação.}

Um segundo experimento foi elaborado para averiguar se as referidas formas de marcação poderiam interferir na atividade dos insetos estudados.

Marcaram-se as respectivas espécies da mesma forma descrita no teste anterior. Após o teste, as cigarrinhas foram liberadas numa das extremidades de uma gaiola medindo $2 \mathrm{~m}$ de comprimento por 80 de altura e 80 de largura. Na outra 
extremidade foi colocada uma muda cítrica e uma fonte de luz. Utilizou-se 8 cigarrinhas marcadas e 8 não marcadas de cada espécie. Avaliou-se quantas cigarrinhas marcadas e não marcadas foram para a extremidade oposta a de suas liberações. Foram feitas avaliações aos 5, 20 e 60minutos após a liberação das cigarrinhas marcadas.

Depois de comprovada a não interferência da marcação na mortalidade e na atividade das cigarrinhas marcaram-se 120 de Oncometopia sp. com esmalte amarelo; 120 de Dilobopterus costalimai e 120 de Acrogonia sp. com pó fluorescente de cor laranja. Depois de marcadas, as cigarrinhas foram levadas ao campo onde já estavam instaladas as armadilhas adesivas de atração por cor amarela.

\subsubsection{Liberação das cigarrinhas}

A forma de liberação foi a mesma para os dois tipos de marcação: As mudas que continham as cigarrinhas foram dispostas em quatro lados da planta do campo considerada o centro de liberação e os filós que confinavam as cigarrinhas às mudas foram retirados cuidadosamente, de modo a não perturbar os insetos. No entanto, das cento e vinte marcadas, para cada espécie, encontrou-se mortas no filó e no fundo do vaso que continha as cigarrinhas no momento da liberação 12,16 e 23 indivíduos de Acrogonia sp., $O$. facialis e D. costalimai respectivamente. Portanto foram liberadas efetivamente, 108, de Acrogonia sp., 104 de $O$. facialis e 97 cigarrinhas $D$. costalimai. O horário da liberação foi às 17:30 horas.

\subsubsection{Avaliação}

O horário das avaliações era às 17:30 horas. Foram feitas 7 avaliações por sete dias seguidos para cada uma das espécies estudadas.

Os dados obtidos, ou seja, o número de indivíduos recapturados de cada espécie, foram contrastados com a distância da armadilha até o centro de dispersão, através de regressão linear. 
A localização exata em relação à mata foi representada em figuras.

\subsection{Período de atividade, distribuição vertical, e preferência microclimática.}

Os insetos utilizados nesse experimento foram coletados em pomar comercial situado no município de Colina-SP. Esses insetos foram transportados em mudas cítricas cobertas com alvéolo e aspergidas com gotículas de água durante a viagem do campo em Colina-SP até o Laboratório do Departamento de Entomologia da ESALQUSP em Piracicaba, onde foram acondicionados em ambiente com temperatura de $25{ }^{\circ} \mathrm{C} \pm 3$, e Umidade em cerca de $70 \%$. Os insetos permaneciam 1 dia neste ambiente e depois de sexados eram levados ao campo.

No pomar experimental da ESALQ-USP, em Piracicaba-SP, uma planta de da variedade Pêra com idade de 6 anos foi infestada com 7 casais previamente sexados de cada uma das seguintes espécies: Acrogonia sp., Oncometopia facialis e Dilobopterus costalimai. Os machos foram marcados por ocasião da sexagem. A marcação foi feita pincelando-se o inseto com um pó fluorescente alaranjado nas duas espécies primeiramente citadas e com um toque de esmalte nos indivíduos de $O$. facialis.

Os insetos foram confinados à planta por meio de uma gaiola a qual a envolvia completamente. As dimensões da gaiola eram: $2,7 \mathrm{~m}$ de largura x $2,7 \mathrm{~m}$ de comprimento $\times 2,7 \mathrm{~m}$ de altura. Ela foi montada sobre a planta de modo a não tocar nas extremidades dos ramos. As dimensões da árvore eram: $2,2 \mathrm{~m}$ de altura $\mathrm{e}$ diâmetro médio de $1,90 \mathrm{~m}$.

Foi colocado um termoidrógrafo no interior da copa e outro afastado $10 \mathrm{~cm} \mathrm{da}$ extremidade dos ramos laterais a uma altura de 1,4 m do chão.

As avaliações foram visuais. Todos os ramos da planta foram inspecionados da base até a extremidade. A árvore não foi agitada durante a avaliação para não influir no deslocamento dos insetos sobre a planta. As inspeções foram feitas às 5:00, 8:00, 10:30, 13:30, 17:30: 20:00 horas

Foram avaliados: 


\begin{abstract}
a) espécie do inseto encontrado;
b) sexo do inseto;

c) posição vertical do inseto em relação à planta: terço inferior, médio ou superior;

d) posição em relação ao ramo: ramo novo, ramo suberificado, folha nova, folha velha.

O teste foi repetido 8 vezes, nas datas de 25, 28 de março, 2, 5, 12, 15, 23 e 30 de abril de 1999. As médias dos resultados obtidos foram calculadas e analisadas graficamente.
\end{abstract}

\title{
3.3. Local de pouso dos cicadelídeos dos citros.
}

O experimento foi instalado em 23 de maio de 1998 em um pomar comercial localizado em Catanduva-SP contendo plantas da variedade Pêra com cerca de 5 anos de idade. Nesse pomar, foram escolhidas 12 árvores ao acaso. De cada terço da planta, superior, médio e inferior, foram tomados $50 \%$ dos ramos, e estes foram pulverizados com "stiker" líqüido desde a extremidade até a base. $\mathrm{O}$ stiker usado é fabricado pela Olson Products, Inc. sob o nome comercial de Stiky Stuff e sua constituição química ativa são copolímeros de acetato de vinila. $\mathrm{O}$ "stiker" era incolor e não atrativo, portanto os insetos ocorrentes no pomar, ao escolher uma planta, teoricamente, teriam a mesma probabilidade de pousar na área com cola ou na sem cola. Antes de se aplicar a cola às plantas estas foram sacudidas de modo a espantar as cigarrinhas que aí, eventualmente, se encontravam. 0 índice de $50 \%$ de ramos pulverizados visou a não cobertura total da área foliar da planta para que a falta de transpiração não comprometesse a planta.

As avaliações foram feitas às: 8:00, 10:00, 12:00, 15:00 e 18:00 horas diariamente durante a primeira semana.

Foram avaliados:

a) distribuição vertical das cigarrinhas pousadas: terço superior, médio ou inferior; 
b) o número de cigarrinhas que pousou em cada face da planta.

Para efeito de comparação, foi montado outro teste em um campo adjacente, onde foram colocados cartões adesivos amarelos $(7,5 \times 12 \mathrm{~cm}) \mathrm{em} 12$ plantas nos terços inferior $(1,10 \mathrm{~m}$ de altura), médio $(1,80 \mathrm{~m})$ e superior $(2,50 \mathrm{~m})$ das árvores. Considerando que os tratamentos foram as 3 alturas de colocação dos cartões adesivos, foram usadas 4 repetições, com 4 armadilhas por altura, em cada uma das faces da planta (norte, sul, leste e oeste) e em quatro árvores diferentes tomadas ao acaso no pomar.

Foram avaliados:

a) distribuição vertical das cigarrinhas pousadas: terço superior, médio ou inferior;

b) número de cigarrinhas que pousou nas armadilhas em cada face da planta.

\subsection{Ação do vento na dispersão de Oncometopia facialis}

Os insetos utilizados nesse experimento foram coletados em pomar comercial situado no município de Colina-SP. no dia 20 de janeiro de 1998 Essas cigarrinhas foram transportados em mudas cítricas cobertas até o Laboratório to Departamento de Entomologia da ESALQ-USP em Piracicaba., onde o experimento foi executado no dia 22 de janeiro de 1998. O laboratório apresentava temperatura de $24^{\circ} \mathrm{C} \pm 2$, e umidade relativa do ar de $70 \%$, Foi usada uma gaiola medindo $2 \mathrm{~m}$ de comprimento por $0,8 \mathrm{~m}$ de largura e $0,8 \mathrm{~m}$ de altura. Em uma das extremidades da gaiola, foi acoplado o bocal de saída de um turboatomizador. Este teve a função de produzir ventos de velocidades conhecidas. Cada mudança na rotação do motor desse equipamento correspondeu uma variação na velocidade de vento, a qual foi aferida por meio de um anemômetro digital. Assim, foram testadas as seguintes velocidades

de vento, em metros por segundo: $3,5,9,12,15,18$ 21, e 25 . A cada tratamento corresponderam 4 cigarrinhas confinadas em uma muda de citros pelo período 
minimo de 15 minutos. Esta muda foi colocada dentro da gaiola a dez centimetros do bocal do turboatomizador.

Foram usadas 3 repetições e 9 tratamentos incluindo a testemunha com 4 cigarrinhas cada uma, totalizando 108 insetos.

Avaliou-se o número de indivíduos de Oncometopia facialis que se desprenderam da muda cítrica. Os dados transformados em $\sqrt{\mathrm{x}+0,5}$ e foram submetidos à análise de variância, usando-se $o$ teste $F$ de significância $e$ teste Tuckey para diferenciação das médias. 


\section{RESULTADOS E DISCUSSÃO}

\subsection{Determinação do modelo de dispersão dos insetos.}

Notou-se que Oncometopia facialis apresentou a maior dispersão: 37,5 metros em todas as direções (figura 1, 2 e 3). Esta espécie foi a que mais tempo permaneceu sendo capturada pelas armadilhas, provavelmente por apresentar maior atividade. Ela O. facialis e $D$. costalimai foram mais encontradas na planta central $(38,57 \%$ e 28,57 respectivamente) do que Acrogonia sp. (7,6\%). D. costalimai e Acrogonia sp. apresentaram uma dispersão de 25 e 30 metros respectivamente (figuras 1 e 2), sob as

condições do teste. Porém Acrogonia sp. mostrou maior tendência em se dirigir para a direção da mata, o que foi evidenciado pelo fato de $69 \%$ dos indivíduos de recapturados es.arem em armadilhas do lado da mata vizinha ao pomar, cerca de 20 metros do $5^{\circ}$ círculo. Contra apenas $42,6 \%$ no caso de $D$. costalimai . 
Tabela 1. Número de Acrogonia sp. recapturadas por círculo de armadilhas no período de 6 a 10 de setembro de 1988 a partir da liberação de108 indivíduos em pomar cítrico em Piracicaba-SP.

\begin{tabular}{lccccc}
\hline \hline & $1^{0}$ dia & $2^{0}$ dia & $3^{0}$ dia & $4^{0}$ dia & $5^{0}$ dia \\
\hline Planta central & 3 & 1 & - & - & - \\
Circulo 1 & 1 & 2 & 1 & - & - \\
Círculo 2 & - & 1 & - & 1 & - \\
Círculo 3 & - & - & 1 & 1 & - \\
Círculo 4 & - & - & - & 1 & - \\
Círculo 5 & - & - & - & - & \\
\hline
\end{tabular}

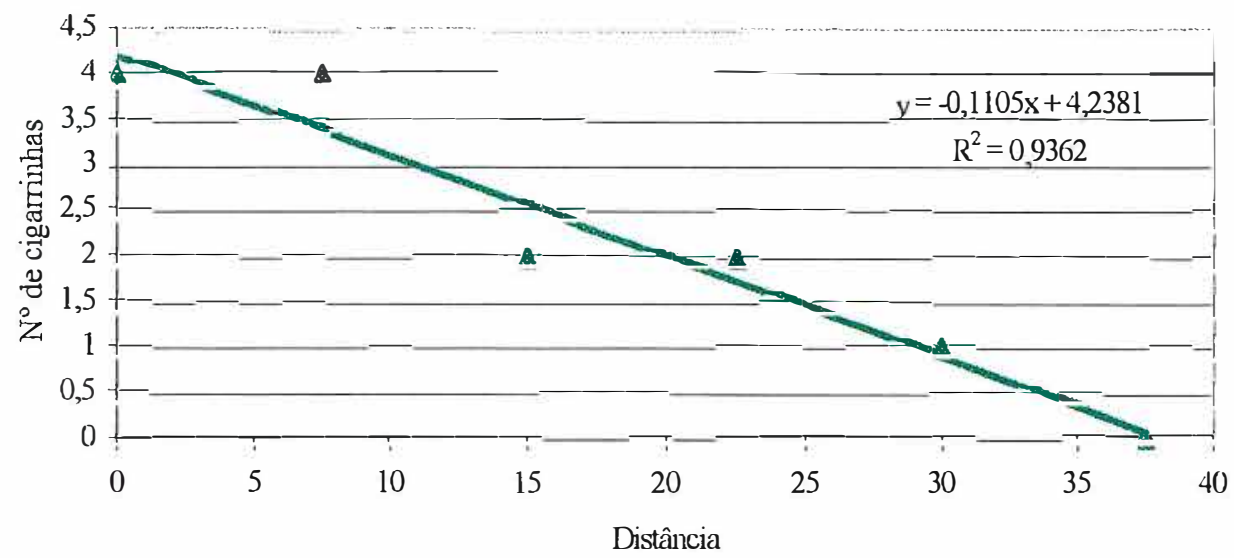

Figura 1. Regressão linear entre o número de indivíduos de Acrogonia sp. recapturados em cada circulo e a distância das armadilhas até o centro de dispersão. 
Tabela 2. Número de Dilobopterus costalimai recapturadas por círculo de armadilhas no período de 15 a 19 de setembro a partir da liberação de 104 indivíduos em pomar cítrico em Piracicaba-SP.

\begin{tabular}{lccccc}
\hline & $1^{\circ}$ dia & $2^{\circ}$ dia & $3^{\circ}$ dia & $4^{\circ}$ dia & $5^{\circ}$ dia \\
\hline Planta central & 2 & 1 & 1 & 1 & - \\
Circulo 1 & 1 & 2 & - & - & - \\
Círculo 2 & - & 1 & 1 & 1 & - \\
Círculo 3 & - & - & - & 1 & - \\
Círculo 4 & - & - & - & - & - \\
Círculo 5 & - & - & - & - & - \\
\hline
\end{tabular}

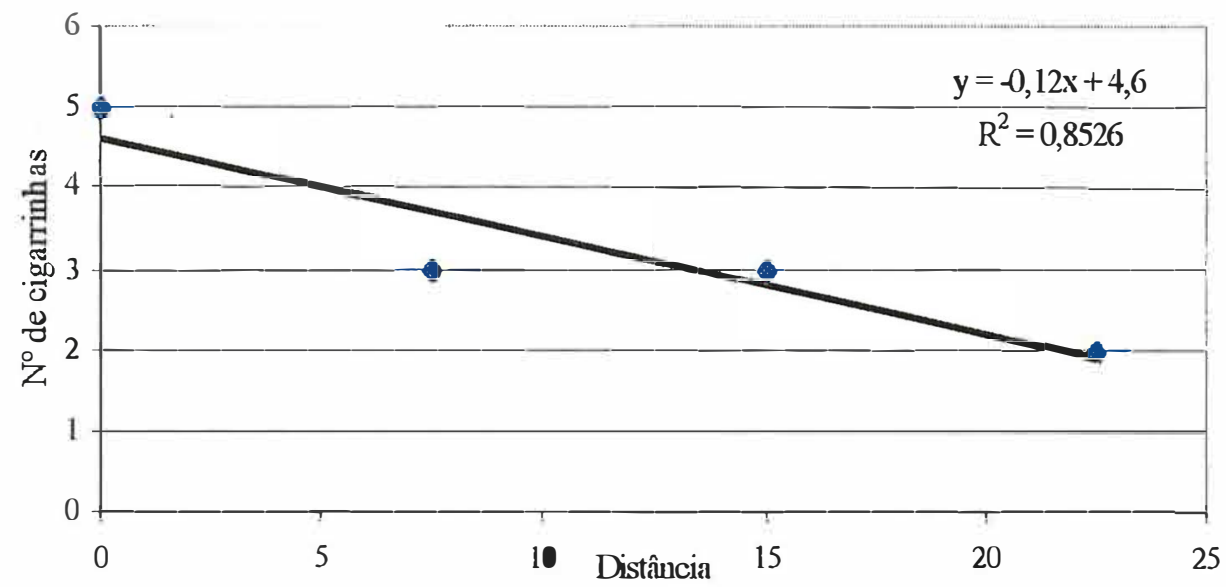

Figura 2. Regressão linear entre o número de indivíduos de Dilobopterus costalimai recapturados em cada circulo e a distância das armadilhas até o centro de dispersão. 
Tabela 3. Número de Oncometopia facialis recapturadas por círculo de armadilhas no período de 15 a 19 de setembro a partir da liberação de 97 indivíduos em pomar cítrico em Piracicaba-SP.

\begin{tabular}{lccccc}
\hline & $1^{0}$ dia & $2^{0}$ dia & $3^{0}$ dia & $4^{0}$ dia & $5^{\circ}$ dia \\
\hline Planta central & 2 & 1 & 1 & - & - \\
Circulo 1 & 1 & 1 & 1 & 1 & - \\
Círculo 2 & 1 & - & - & 1 & - \\
Círculo 3 & - & - & 1 & - & 1 \\
Círculo 4 & - & - & - & - & - \\
Círculo 5 & - & - & 1 & - & \\
\hline
\end{tabular}

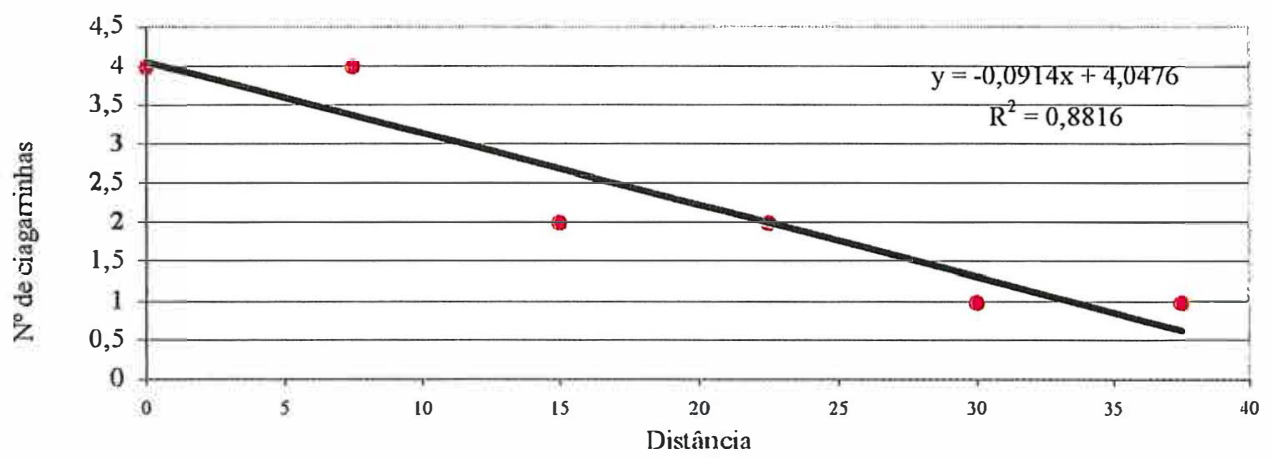

Figura 3. Regressão linear entre o número de indivíduos de Oncometopia facialis recapturados em cada circulo e a distância das armadilhas até o centro de dispersão. 


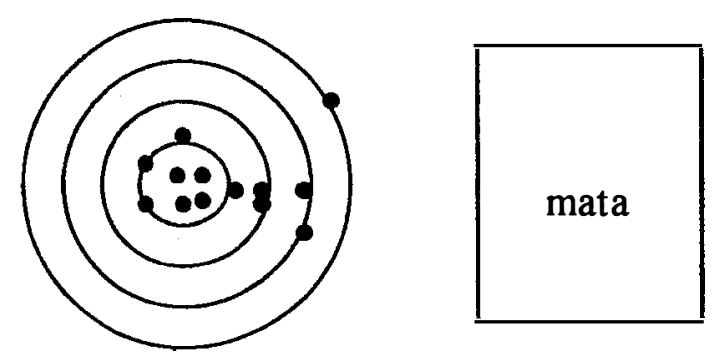

Figura 4. Localização relativa dos indivíduos de Acrogônia terminalis recapturados, durante 5 dias após a liberação de 107 indivíduos em pomar cítrico em Piracicaba-SP.
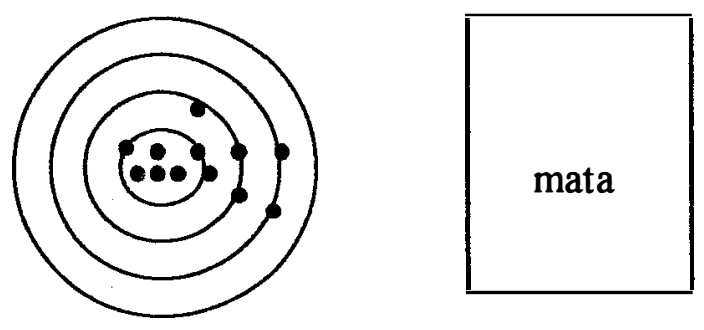

Figura 5. Localização relativa dos indivíduos de Dilobopterus costalimai recapturados, durante 5 dias após a liberaçãode 104 indivíduos em pomar cítrico em Piracicaba-SP.

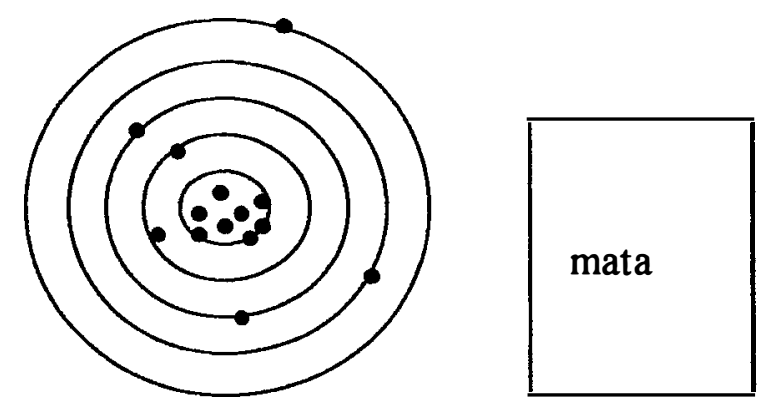

Figura 6. Localização relativa dos indivíduos de Oncometopia facialis recapturados, durante 5 dias após a liberação de 97 indivíduos em pomar cítrico em Piracicaba-SP. 
Os resultados sobre dispersão de Acrogonia sp. concordam com Almeida et al. (1997), que afirmam que a distribuição dessa espécie em um pomar é agregada e que grande parte dos insetos permanecem próximo as matas (figuras 4, 5 e 6). É notável que $D$. costalimai foi a espécie que menos tempo permaneceu sendo capturada. Este fato indicou que os indivíduos dessa população deslocaram-se rapidamente em busca de um bom hospedeiro, no qual tendem a permanecer por longo tempo. Provavelmente elas procuraram plantas com brotações, onde poderiam se alimentar e assim que encontraram permanecem no local, de onde sairiam apenas para realizar acasalamento, postura ou para fugir de algum predador natural.

Com base nestas informações pode-se-ia propor um modelo de colonização de um pomar por cicadelídeos vetores:

Os insetos ao virem de um campo infectado vizinho, para um pomar novo de mudas sadias, avançariam cerca de 30 metros em 5 dias, colonizando cerca de 4 ruas. A partir dessas ruas dispersar-se-iam em todas as direções porém, no caso de $D$. costalimai, com cerca de $46,2 \%$ de tendência a voltar em direção à mata e com $15,3 \%$ de dispersão em todas as outras direções, além das $38,5 \%$ que ficariam na planta em que estavam.

Numa situação hipotética, de 100 insetos se dispersando de uma única planta, após 5 dias, tempo para máxima dispersão observável, $46 \%$ das cigarrinhas iriam para a mata e $15 \%$ dos insetos iriam para outras partes do pomar. Após mais 5 dias mais $46 \%$ dos insetos, ou seja 21 indivíduos continuaram avançando para a mata e 2,21 indivíduos foram para o centro do pomar. No entanto, teoricamente, e apenas para efeito de facilitar o raciocínio, ponderai-se considerar que aos 38,5 insetos que ficaram na planta inicial, ponderai-se aplicar as mesmas probabilidades de novamente $38 \%$ dos insetos desses 38 insetos ficarem, $15 \%$ dos 38 insetos irem para o pomar e $46 \%$ para a mata.

0 mesmo se aplicaria à Acrofonia sp., porém considerando-se as probabilidades encontradas para esta espécie, que foram de $69 \%$ de chances de migração em direção à mata, $7,6 \%$ de chances de ficar na planta e $23,1 \%$ de chances de ir no sentido do pomas. 
As proporções encontradas para Oncometopia facialis foram $28,57 \%$ de probabilidade de ficarem na mesma planta, $28,57 \%$ de probabilidade de irem para plantas em direção ao pomar e $42,86 \%$ de chances de irem para plantas do lado da mata

Considerando que a direção da mata não é uma única, e tampouco o é, a direção do centro do pomar, e que as cigarrinhas se dispersam em várias direções no sentido da mata ou do pomar, vislumbra-se que as probabilidades citadas estão distribuídas em áreas e não em metros lineares de uma única direção e dois sentidos opostos. Ainda, considerando que á área era um pomar de plantas espaçadas de 7,5 metros as probabilidades ficam distribuídas sobre as plantas e não propriamente sobre a área total do pomar. As plantas consideradas como na direção da mata foram as inseridas na área delimitada pelos raios que partem da planta central, onde foram liberados as cigarrinhas, até o limite da mata (figura 7). 


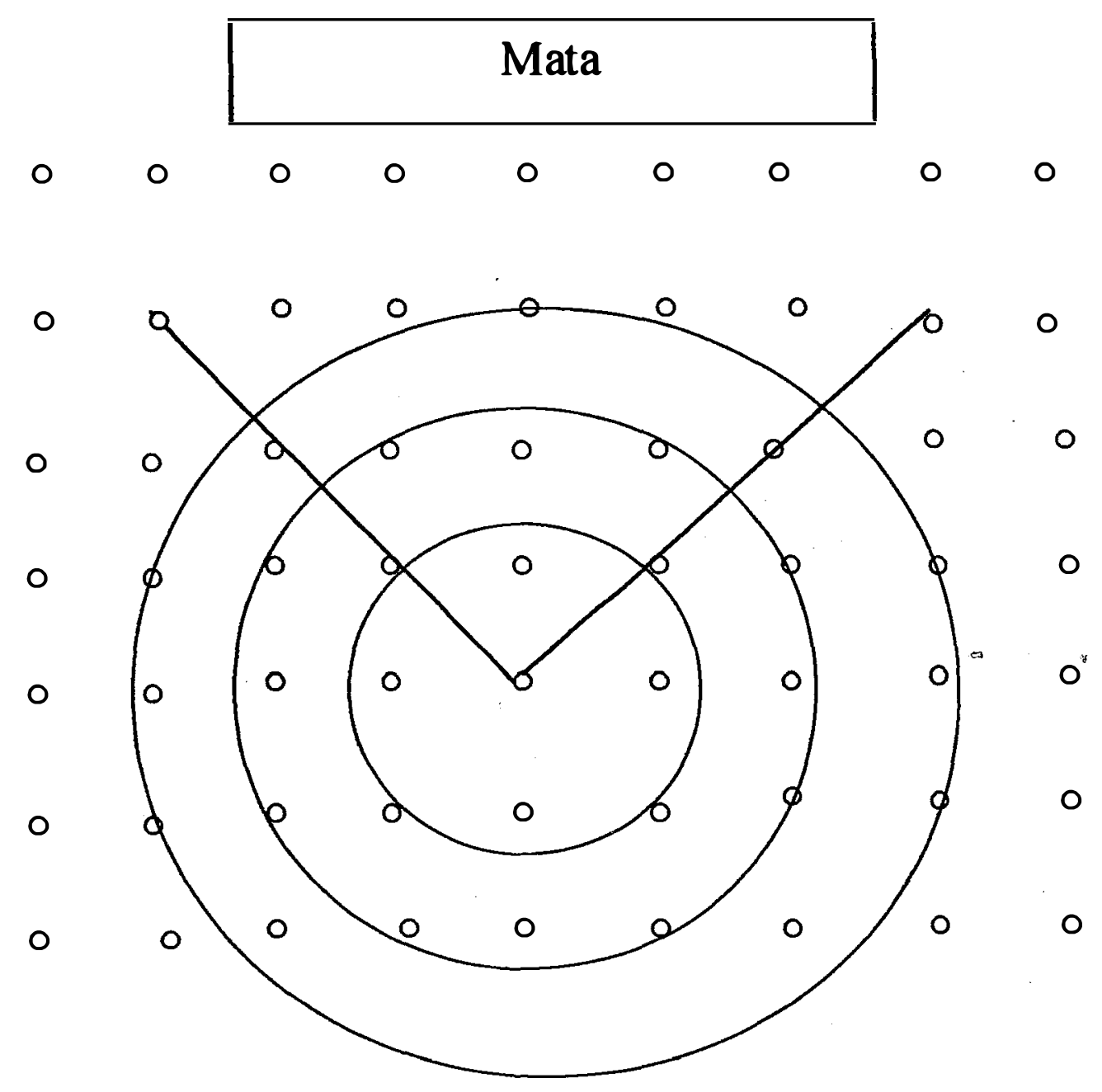

Figura 7 Esquema direções de dispersão das cigarrinhas em um pomar com mata adjacente

Traçando um paralelo entre os resultados de Laranjeira et al. (1998b), para a evolução epidemiológica da doença e os resultados dos experimentos de dispersão dos vetores aqui obtidos, pode-se conjecturar o seguinte: 
Laranjeira et al. (1998b) encontraram que com até $30 \%$ de incidência da doença, as reboleiras não ultrapassaram 10 plantas e isto representava $83 \%$ dos total de focos. Para transmitir a doença a 9 plantas, em um pomar de espaçamento de $7,5 \times 7,5 \mathrm{~m}$, os vetores, partindo de uma planta infectada, deveriam apenas voar para a vizinha, percorrendo $7,5 \mathrm{~m}$ ou traçando uma hipotenusa de $9 \mathrm{~m}$. Nota-se que $66,67 \%$, de Acrogonia sp.; 66,67 de D. costalimai e $60 \%$ de $O$. facialis recapturadas foram encontradas no primeiro círculo (figuras, 4,5 e 6 ). No experimento de Laranjeira, apenas $11 \%$ dos focos da doença apresentaram entre 11 e 50 plantas, e somente $6 \%$ dos focos apresentaram mais que 50 plantas. Eles verificaram, ainda, que quando a incidência de doença superava $40 \%$ de plantas com sintomas, o comprimento dos focos sofria aumento que seria provocado pela forma do talhão. No caso Acrogonia sp. e $D$. costalimai, e $O$. facialis ficou evidenciado que elas se dispersam $69,23 \%$ $, 46,15 \%$ e 42,86 respectivamente em direção à mata. Este fato poderia explicar que esses insetos, ao partir de uma planta-inóculo de um determinado ponto de um pomar, ao se dispersarem mais em direção a mata, poderiam transmitir a doença mais nessa direção e assim propiciar a evolução do foco de modo a deixá-lo com uma dimensão maior que a outra, ortogonal, isto é os focos ficariam com aspecto alongado. 


\subsection{Período de atividade, local de permanência, preferência microclimática.}

Os resultados dos testes prévios de influência da marcação sobre a mortalidade e a atividade dos cicadelídeos estudados mostram com evidência que o número de cigarrinhas que morreram no lote testemunha não diferiu significativamente do lote marcado.

Da mesma forma, o número de cigarrinhas que se deslocaram da planta situada no lado escuro para a planta situada no lado claro não diferiu entre o lote testemunha e o marcado.

Tabela 4. Número de cigarrinhas mortas após a marcação com esmalte em 8 Oncometopia facialis e com pó fluorescente em 8 Acrogonia sp. e 8 Dilobopterus costalimai.

\begin{tabular}{lcccccc}
\hline & \multicolumn{2}{c}{ Acrogonia sp. } & \multicolumn{2}{c}{ D. costalimai } & \multicolumn{2}{c}{ O.facialis } \\
\hline & marcada & Teste & marcada & teste & marcada & Teste \\
\hline 15 min. & 0 & 0 & 1 & 0 & 1 & 1 \\
$24 \mathrm{~h}$ & 0 & 1 & 0 & 1 & 0 & 1 \\
$48 \mathrm{~h}$ & 1 & 0 & 0 & 1 & 1 & 0 \\
\hline
\end{tabular}

Tabela 5. Número de cigarrinhas que foram para o lado iluminado da gaiola após a marcação com esmalte em 8 Oncometopia facialis e com pó fluorescente em 8 Acrogonia terminalis e 8 Dilobopterus costalimai.

\begin{tabular}{lcccccc}
\hline & \multicolumn{2}{c}{ Acrogonia sp. } & \multicolumn{2}{c}{ D. costalimai } & \multicolumn{2}{c}{ O. facialis } \\
\hline & marcada & teste & marcada & teste & marcada & Teste \\
\hline 15 min. & 5 & 5 & 4 & 4 & 3 & 5 \\
$24 \mathrm{~h}$ & 2 & 2 & 3 & 3 & 3 & 3 \\
$48 \mathrm{~h}$ & 0 & 1 & 0 & 1 & 0 & 0 \\
\hline
\end{tabular}


$75 \%$ dos individuos de Acrogonia sp. foram encontrados em folhas novas (figura 10).

$90 \%$ foram encontradas nos terços superior e médio, sendo que, relativamente, foram encontrados mais machos do que fềmeas no terço superior em quase todos os horários com exceção da avaliação das 20:00 horas. Nas avaliações das $08: 30$ horas, foram encontrados $71 \%$ as fềmeas no terço superior e apenas $29 \%$ no terço médio, o que não ocorreu para os machos, que neste horário a diferença entre o número de indivíduos no terço superior e médio foi de apenas $15 \%$. $80 \%$ dos machos que foram para a tela, foram encontrados nas avaliações das 10:30 e 13:30. $77 \%$ das fêmeas que foram para a tela, foram vistas às $17: 30$, e $23 \%$ às 13:30 (figura 8).

87\% das fềmeas e $90 \%$ dos machos de Dilobopterus costalimai foram encontradas em ramos novos e folhas novas (figura 11)

Menos de $5 \%$ dos indivíduos machos e fềmeas de $D$. costalimai foram encontrados no terço inferior da planta. Tanto os machos como fêmeas encontrados na tela foram vistos nas avaliações das 10:30, 13:30 e 17:30 h. No entanto, $83 \%$ dos machos que foram para a tela, foram encontrados às $10: 30$ e $13: 30 \mathrm{~h}$ e apenas $17 \%$ às 17:30 h (figura 9).

$43 \%$ das fềmeas de Oncometopia facialis encontradas foram vistas nas folhas novas, $29 \%$ nas folhas velhas, $21 \%$ nos ramos novos e $7 \%$ nos ramos velhos (figura 13).

Das fềmeas de $O$. facialis encontradas, $42 \%$ estavam no terço superior, $45,8 \%$ no terço médio, $1,6 \%$ no inferior e $10 \%$ na tela (figura 10B). Dos machos de $O$. facialis 
encontradas, $49 \%$ estavam no terço superior, $37,5 \%$ no terço médio, $6,2 \%$ no inferior e $7,2 \%$ se encontraram na tela (figura $10 \mathrm{~A}$ ).
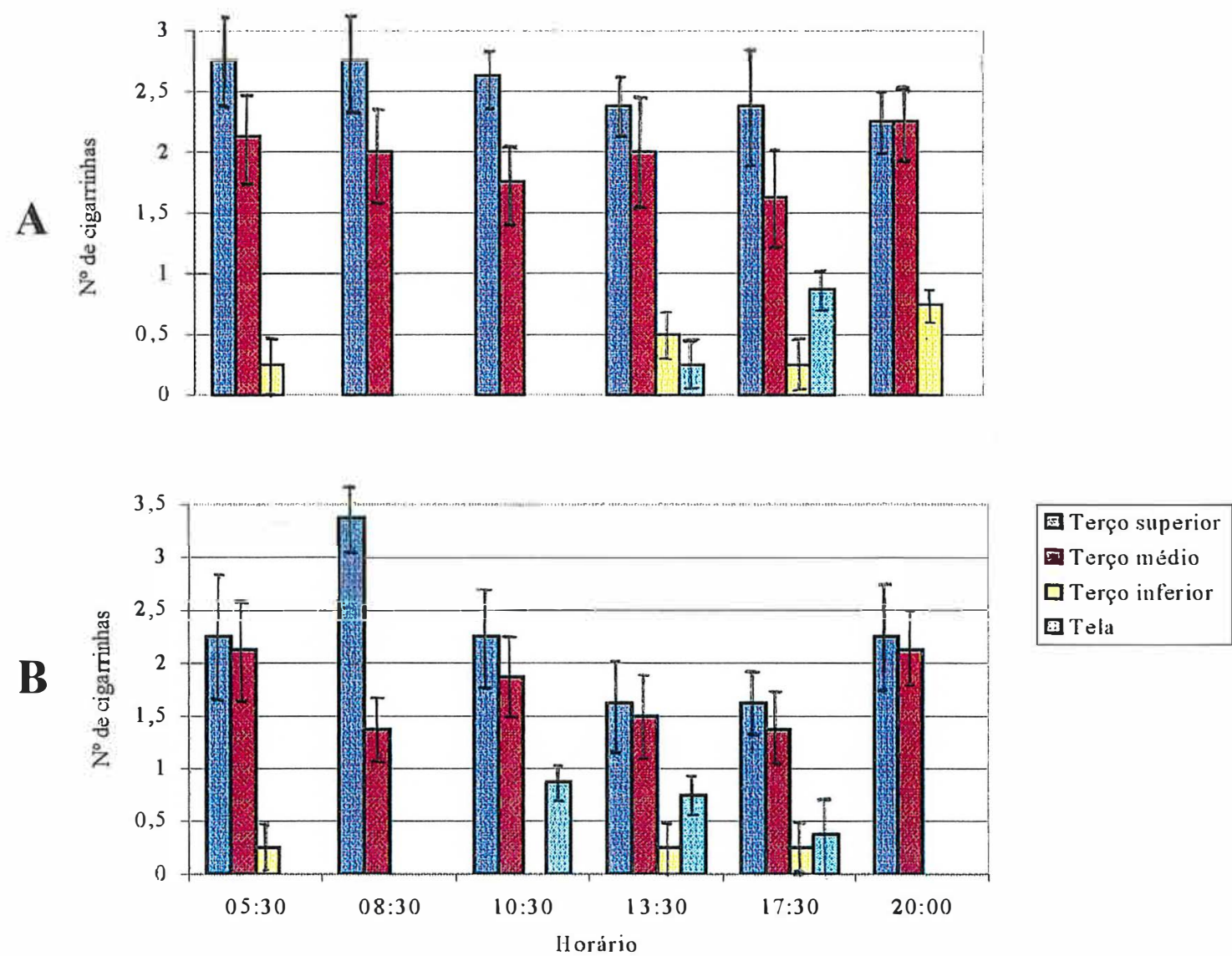

Figura 8 Distribuição vertical de machos (A) fêmeas (B) de Acrogonia sp. em diferentes horários do dia em uma laranjeira de 8 anos de idade . Média de 8 repetições. 

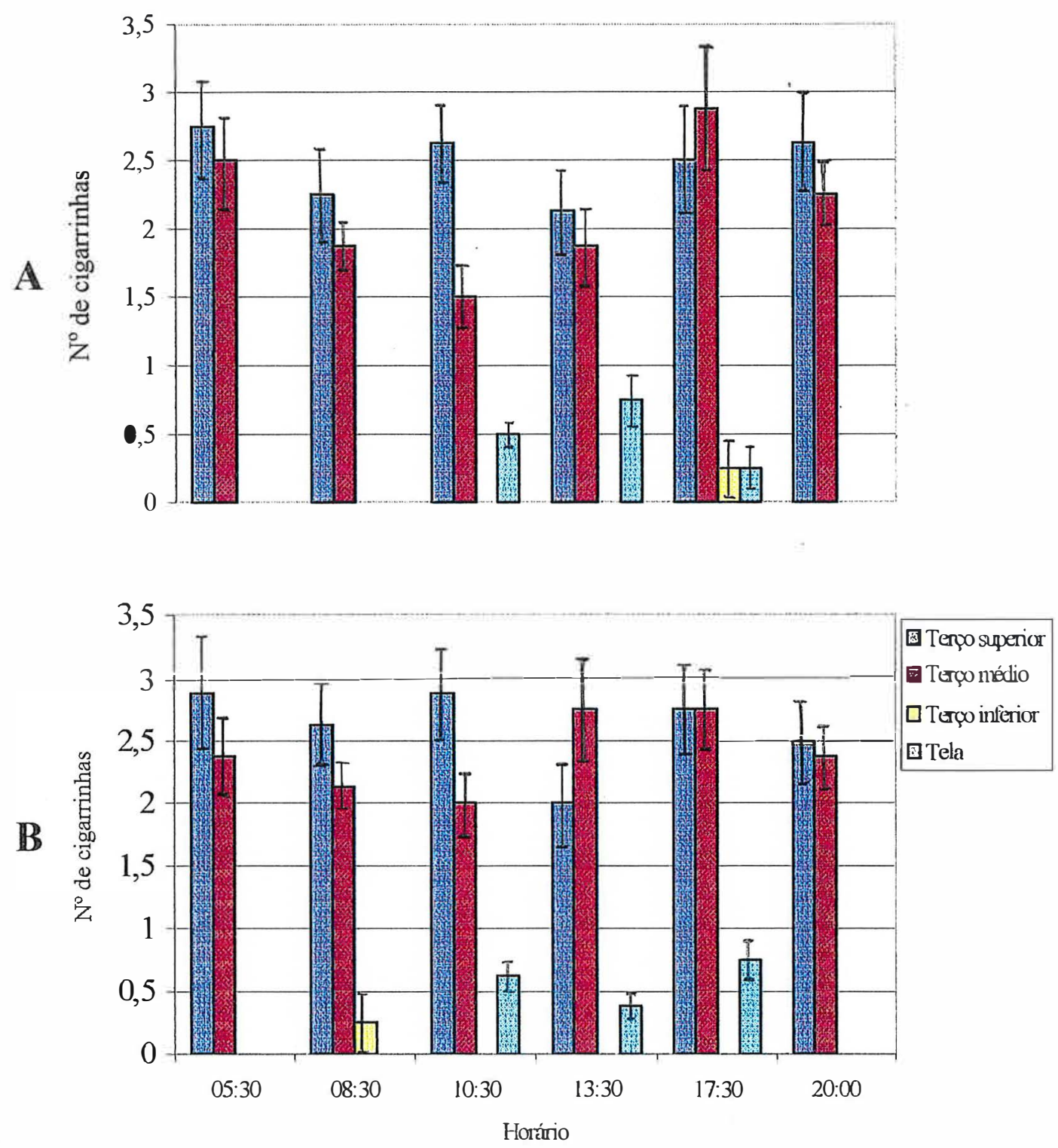

Figura 9 Distribuição vertical de machos (A) e fêmeas (B) de Dilobopterus costalimai em diferentes horários do dia em uma laranjeira de 8 anos de idade. Média de 8 repetições. 

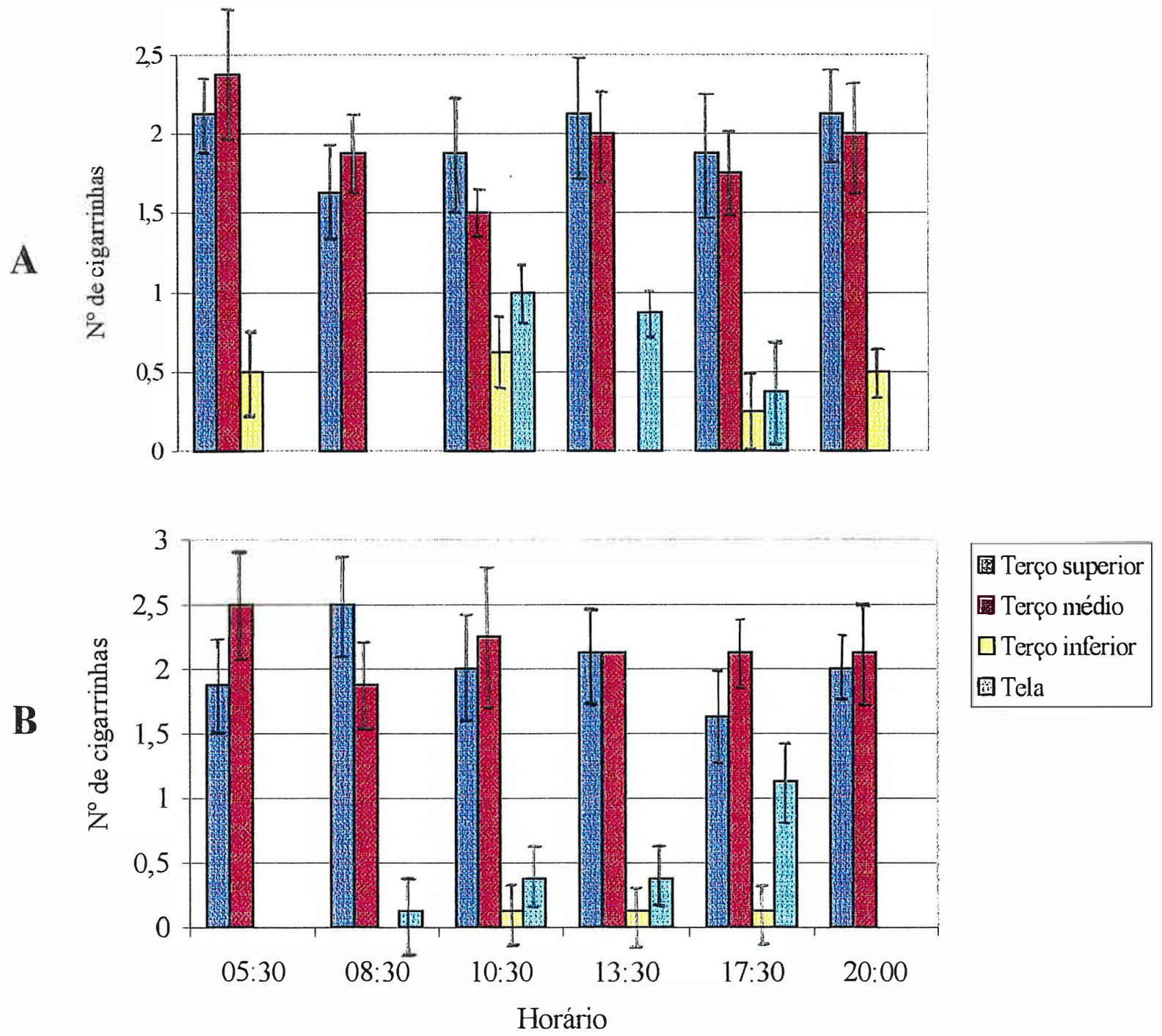

Figura 10 Distribuição vertical de machos (A) e fêmeas (B) de Oncometopia facialis em diferentes horários do dia em uma laranjeira de 8 anos de idade. Média de 8 repetições. 

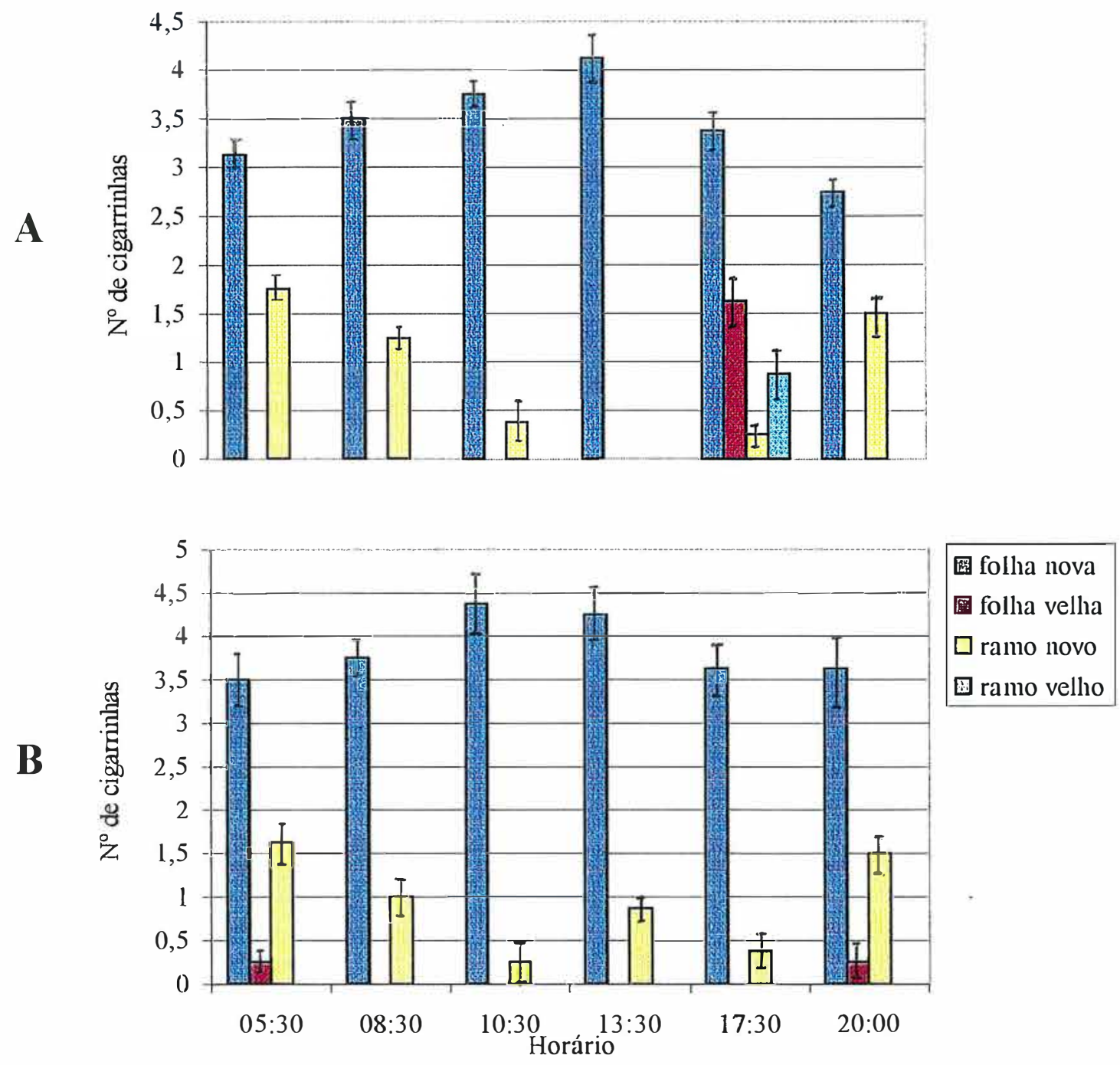

Figura 11 Órgão vegetais de permanência de machos (A) fêmeas (B) de Acrogonia sp. em diferentes horários do dia em uma laranjeira de 8 anos de idade. Média de 8 repetições. 

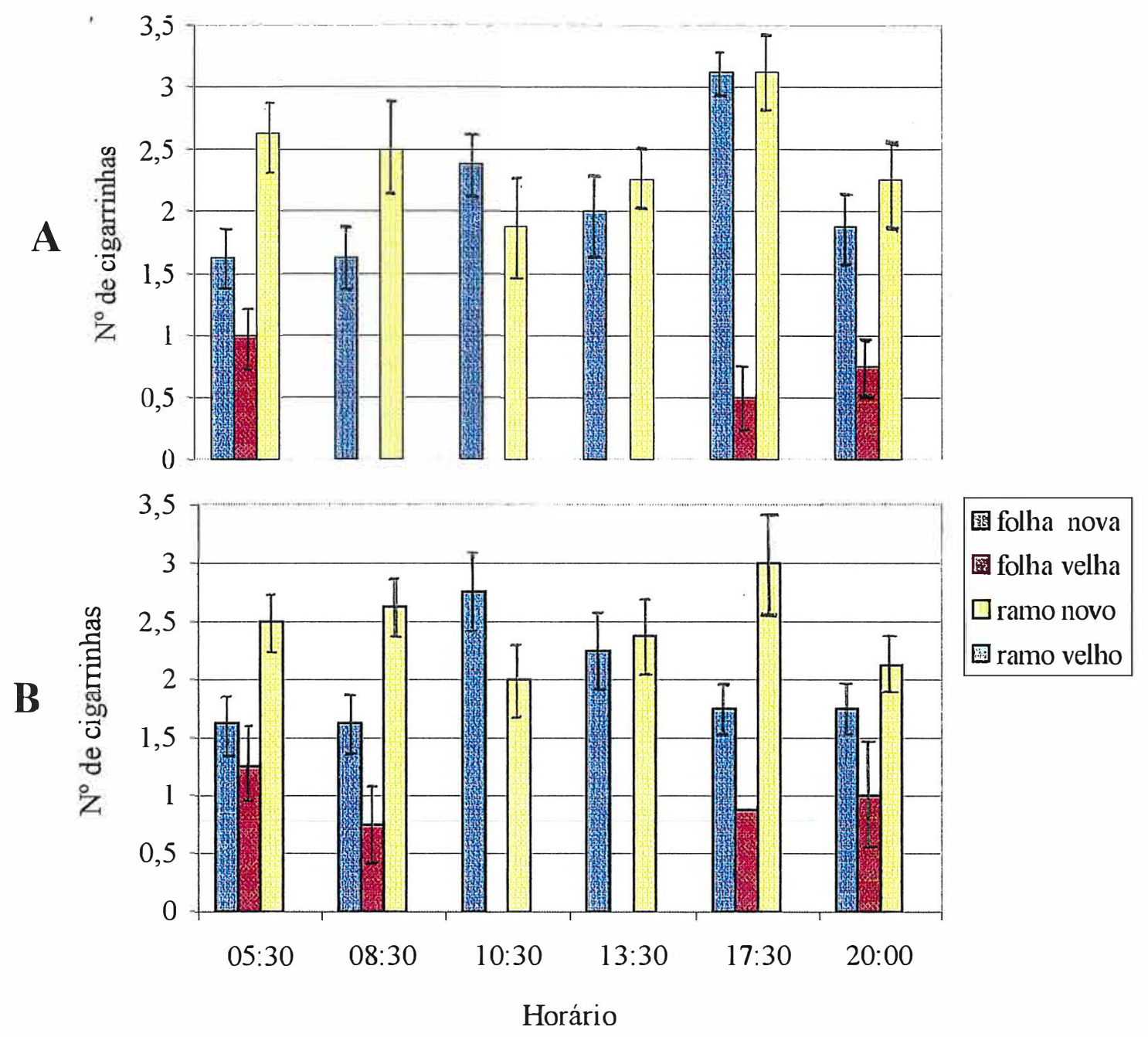

Figura 12 Órgão vegetais de permanência de machos (A) e fêmeas (B) de Dilobopterus costalimai em diferentes horários do dia em uma laranjeira de 8 anos de idade. Média de 8 repetições. 

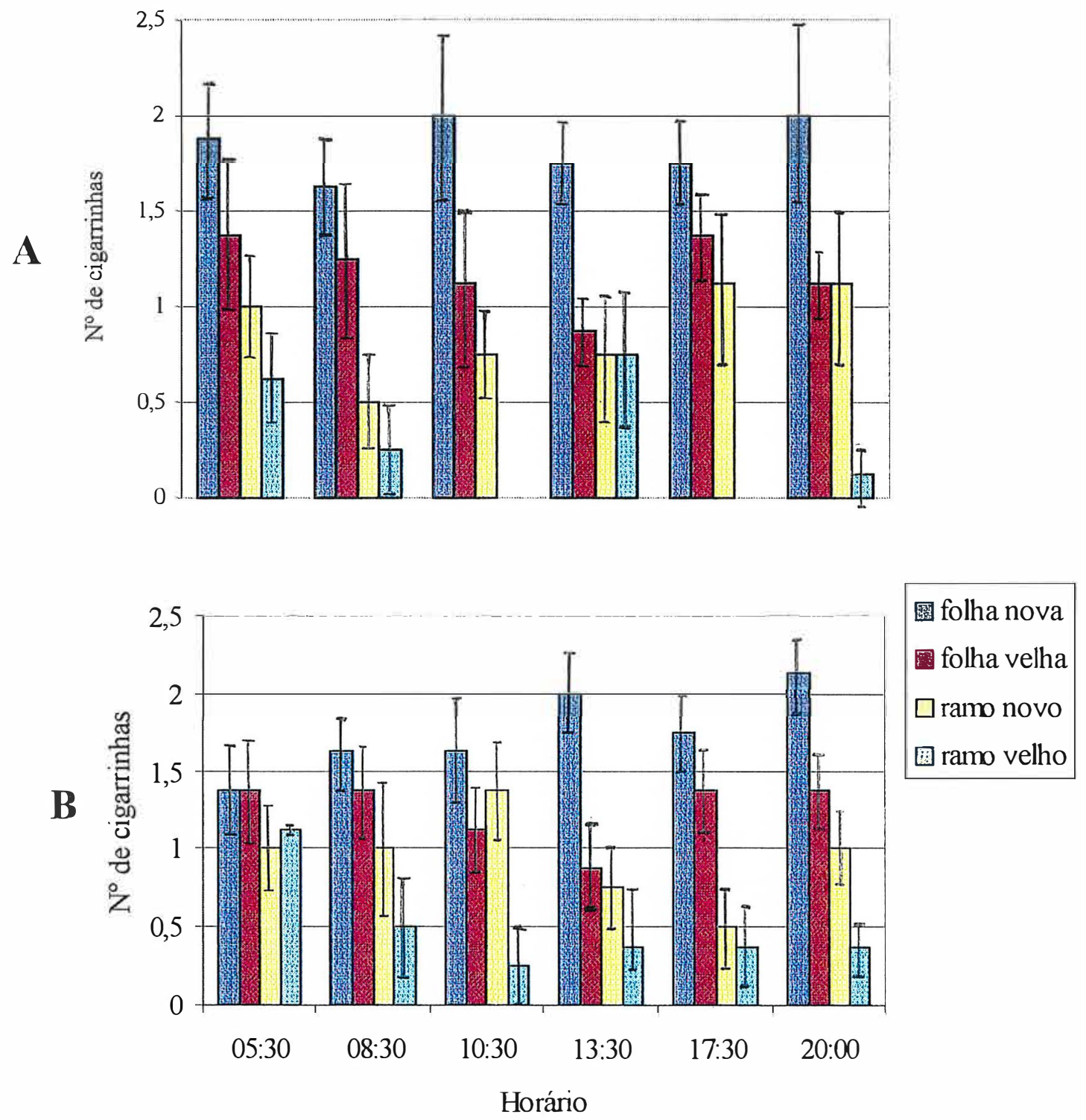

Figura 13 Órgão vegetais de permanência de machos (A) e fêmeas (B) de Oncometopia facialis em diferentes horários do dia em uma laranjeira de 8 anos de idade. Média de 8 repetições. 
Nota-se que Acrogonia sp. teve preferência por localizar-se em folhas novas das partes superior e média da planta em todos os horários avaliados, porém, quando a temperatura foi muito elevada estes insetos tenderam a se esconder da incidência direta dos raios solares debaixo de ramos novos. Ficou evidenciado que esses insetos muito raramente, por casualidade, deixam de permanecer nas partes jovens da planta, seja folha ou ramo, somente em condições microlimáticas muito hostis, elas deixam as extremidades dos ramos novos e folhas novas. Houve uma correlação entre o número de indivíduos de acrogonia que se esconderam nos ramos novos e a temperatura externa à planta. A partir dos $25^{\circ} \mathrm{C}$, quanto mais se elevou a temperatura, menor foi o número de cigarrinhas encontradas na periferia da copa, (figura 14). Como a umidade relativa do ar tem certa correlação com a temperatura, o número dessas cigarrinhas em ramos novos também foi correlacionado com umidade relativa do ar (Figura 15). Os coeficientes angulares para as duas correlações foram semelhantes, porém, de sinais contrários, indicando que a tendência a se esconder foi devida, ao aumento da temperatura e à diminuição da umidade relativa do ar.

$O$ fato de serem encontradas cigarrinhas na tela sugeriu que uma parte da população tende a sair da planta, talvez voar para outra árvore. $\mathrm{O}$ horário de saída da planta foi semelhante para ambos os sexos de Acrogonia sp., porém as fềmeas dessa espécie começaram a sair da planta mais cedo, em torno das $10: 30 \mathrm{~h}$ e os machos começaram a sair da planta no período da tarde na avaliação das 13:30 h e 17:30 h.

Não houve um movimento vertical dessa espécie, ao longo do dia. Mas houve um movimento de saída da planta, possivelmente em direção a outra para fins de dispersão a curta distância. Considerando a tendência a sair da planta, ou a ida para a tela como atividade de vôo do inseto, pode-se dizer com base nesse experimento que o período de atividade desses inseto se deu nos horários mais quentes e iluminados do dia. O fato de não ter havido atividade desses insetos até as 8:30 horas, sugere que

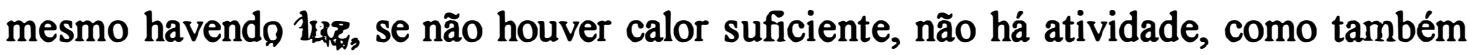


afirmam Lewis \& Taylor (1964) e Rodriguez et al. (1992) citados por Lopes et al. (1995). Lopes et al. (1995). mostraram que, a resposta à luminosidade varia com o sexo, a idade dos adultos de cigarrinhas e verificaram ainda, que, quanto maior a intensidade de luz, menor a taxa de movimento de fềmeas virgens entre plantas.

D. costalimai apresentou ligeira preferência por situar-se no terço superior da planta do que no terço médio e o número desses insetos encontrados no terço inferior foi não significativo. O órgão preferido dessa espécie foi o ramo jovem, porém quando as condições microclimáticas externas apresentaram temperaturas em torno de $20{ }^{\circ} \mathrm{C}$ ou menos, encontrou-se um número maior dessas cigarrinhas nas folhas velhas localizadas no interior da planta (figura 21). Outra observação (figura 12) é que há um certo aumento no número de $D$. costalimai em folhas novas nos horários precedentes ao momento de saída desses insetos da planta. Uma hipótese para explicar o movimento de ramos novos para folhas novas, seria o fato dessa espécie efetuar a postura nesse horário, uma vez que, a maioria das posturas $D$. costalimai são efetuadas nas folhas jovens, conforme relata Lima (1995). Outra hipótese para a explicação desse fato seria um caminhamento que o inseto fez, do ramo para a folha, antes de iniciar o vôo para outra parte da mesma planta ou para outra árvore. Nesse experimento, encontraram-se tanto fêmeas como machos na tela que envolvia a planta no período após às 10:30 h e uma grande parte de fềmeas foram para a tela depois das 17:30 h, indicando que esses insetos preferiram alçar nesse horário um possível vôo de dispersão ou de migração (figura 9). Hunt \& Nault (1991) explicam que os machos e fềmeas virgens de cicadelídeos apresentam movimento entre as plantas na fotofase, como uma função do comportamento para localização de sexo oposto para a cópula. Segundo estes autores os machos voam durante o dia procurando localizar fêmeas virgens. Considerando que os insetos utilizados no presente estudo foram coletados no campo, possivelmente, uma parte das fêmeas utilizadas foram fecundadas e outras não foram. Esse fato pode explicar porque houve um pico de fềmeas encontradas na tela às 10:30 e outro às 17:30. Fêmeas copuladas, e fêmeas virgens apresentam diferentes comportamentos como constatou Hunt (1988) citado por Lopez et al. (1995), que trabalhando com Graminella nigrifons, um 
cicadelídeo que ataca milho, notou que machos e fềmeas virgens, mas não fêmeas copuladas, saem da planta de milho, possivelmente, para se dispersarem a curta distância ou para migrar, quando a intensidade de luz testada simulava o cair da tarde.

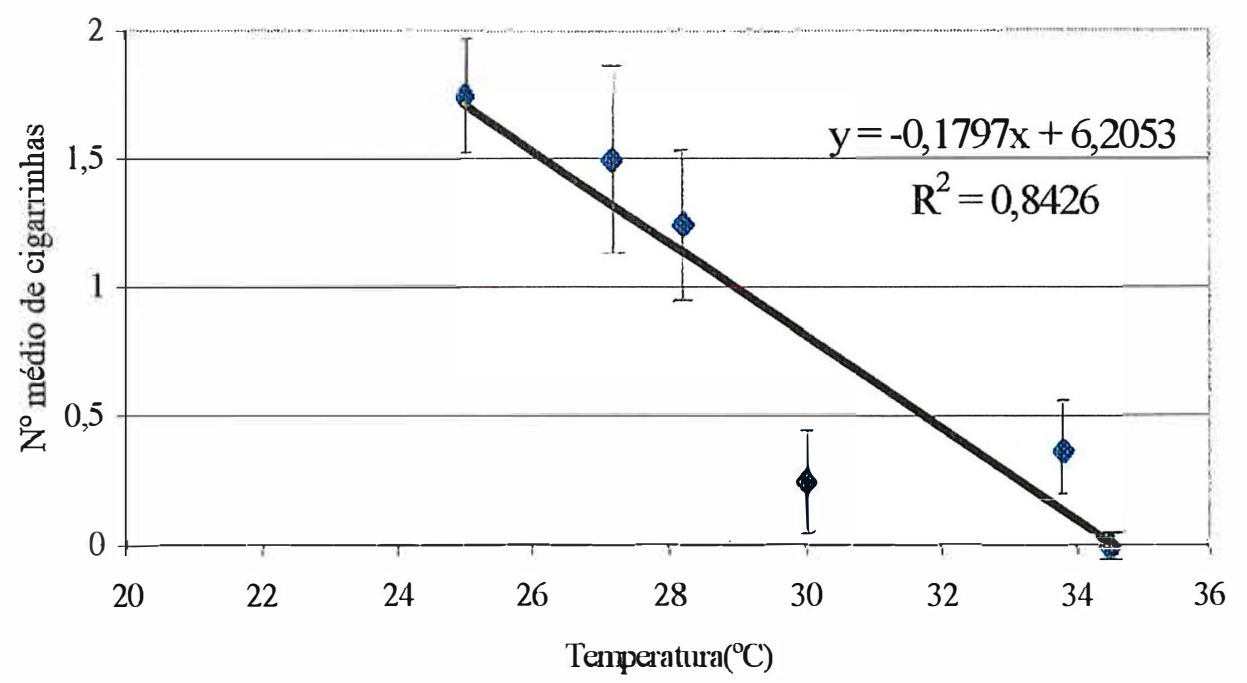

Figura 14 Número de indivíduos machos de Acrogonia sp. na periferia da copa correlacionado com a temperatura do ar neste local. Médias de 8 repetições. 


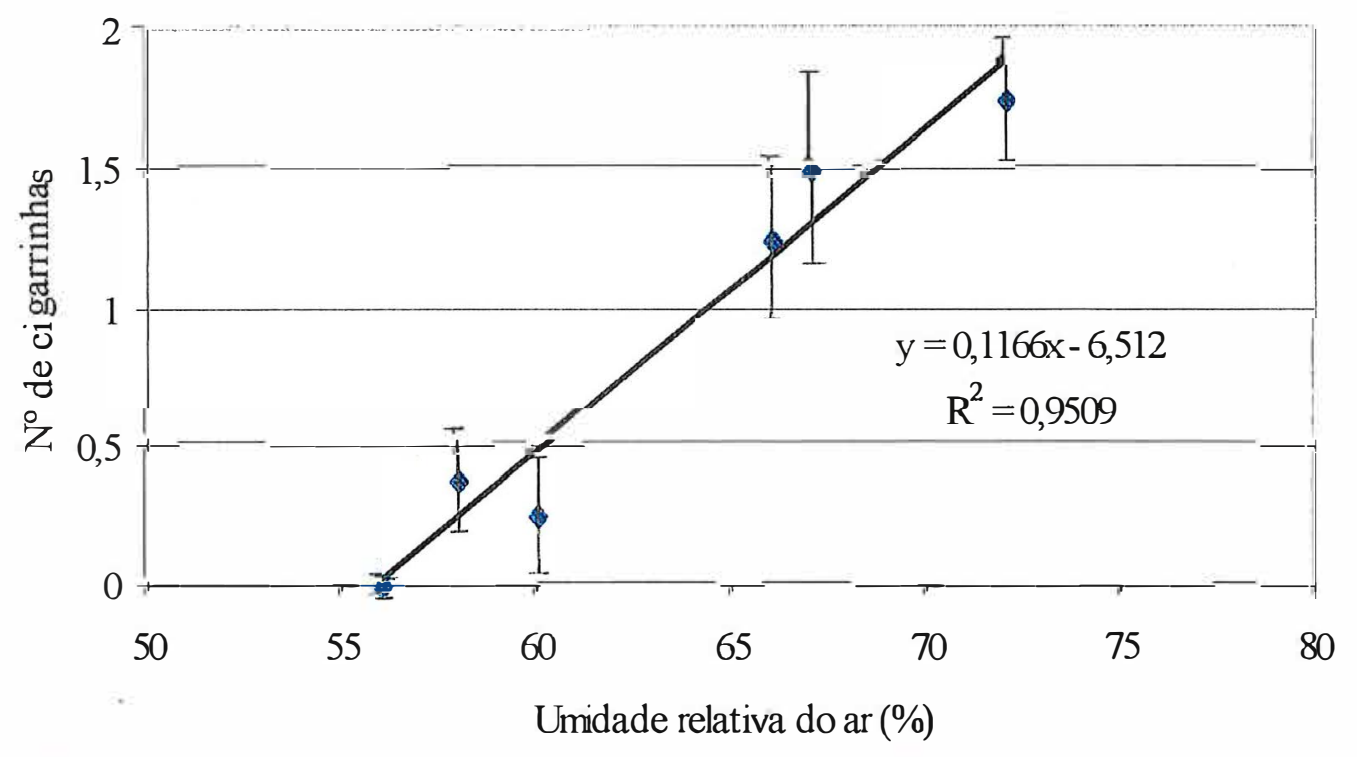

Figura 15 Número de indivíduos machos de Acrogonia sp. na periferia da copa correlacionado com a umidade relativa do ar neste local. Médias de 8 repetições. 


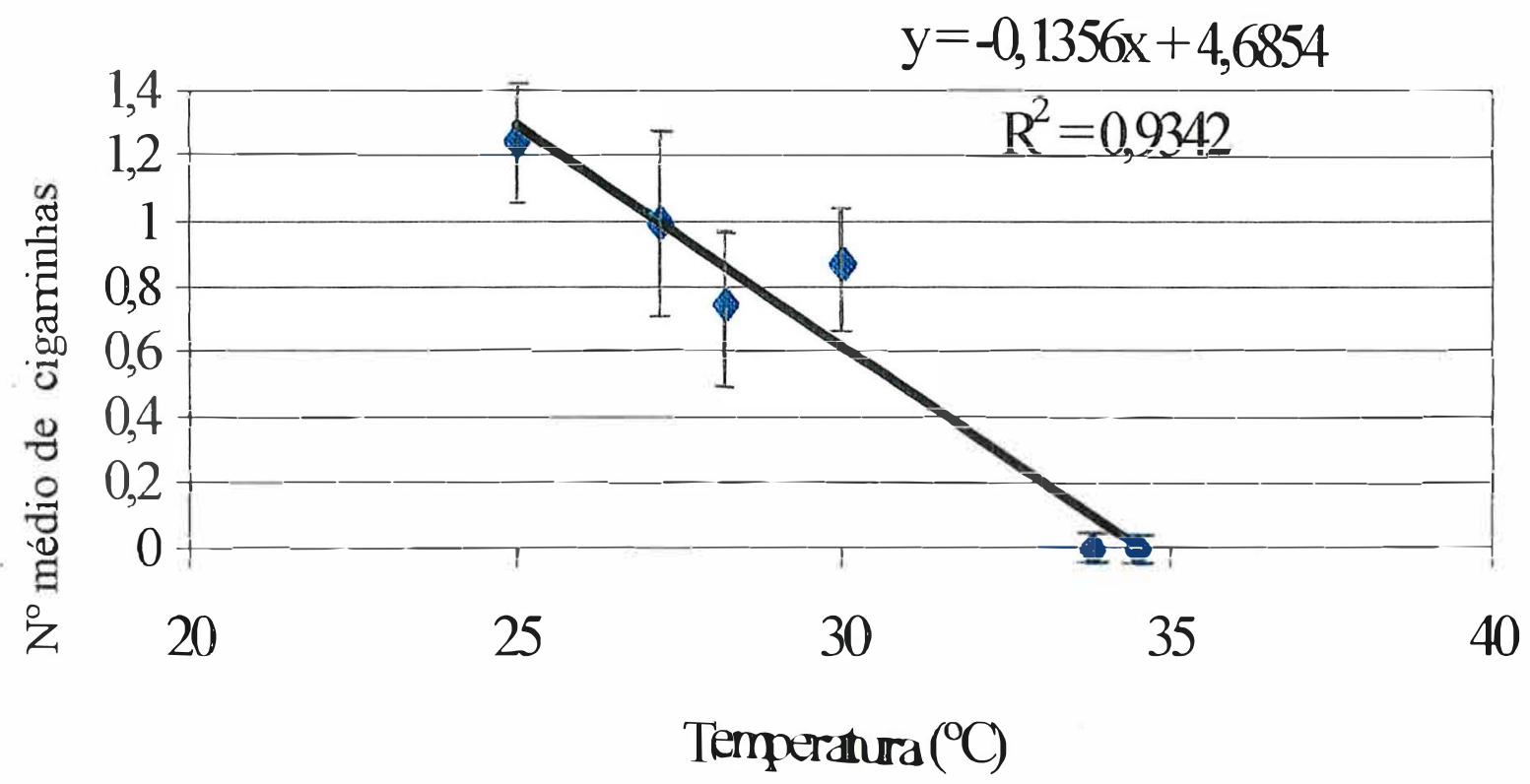

Figura 16 Correlação entre número de fềmeas de Dilobopterus costalimai e temperatura na parte externa da copa.

Oncometopia facialis foi a espécie que se distribuiu mais uniformemente na planta, sendo encontrada em todas as partes vegetais dos dois terços superiores da planta. Ela preferiu localizar-se nas folhas novas, porém cerca de $50 \%$ das cigarrinhas encontradas estavam em outros tipos de órgãos, a maior parte em folhas 
velhas e ramos novos, dependendo do horário. Foram encontrados mais machos do que fêmeas no terço inferior da planta. Observaram-se os machos no terço inferior da planta, nos horários frescos do dia com às 5:30, 17;30 e 20:00 horas (figura 10), mas também constatou-se, que uma parte dos insetos permaneciam no terço inferior da copa na avaliação das 5:30 horas. Lopes et al.(1995), afirmam que a intensidade de luz influencia a distribuição vertical de G. nigrifons em suas plantas hospedeiras e verificaram, ainda que, apesar da distribuição de machos e fềmeas virgens serem semelhantes, as fêmeas iniciam o movimento vertical antes que os machos. Outra observação desse autor é que $G$. nigrifons voava para o topo da planta de milho antes do anoitecer, da mesma forma que $O$. facialis fez um movimento antes de escurecer, porém ao invés de ascendente, foi descendente, ou seja, da tela para a planta antes do cair da noite. Isto pode ser inferido devido à avaliação das 20:00 horas já não mostrar mais insetos na tela. Nota-se que os números de insetos encontrados na tela diferiram entre os sexos, indicando que os machos saíram da planta nos horários mais quentes e as fềmeas, sairam a tarde, com $40 \%$ do total de fêmeas que saíram da planta sendo encontradas na tela por volta das 17:30 horas (figura 10), à semelhança do que ocorreu para a espécie $D$. costalimai (figura 9). Uma inferência sobre este fenômeno, seria a possibilidade das fêmeas copuladas voarem de uma planta para outra para fazerem a postura, possivelmente por preferirem realizar a postura a tardinha o que permitiria maior viabilidade dos ovos recém postos, pois sob as condições noturnas não perderiam umidade como poderia ocorrer sob condições diurnas de umidade e calor.

\subsection{Local e horário de pouso dos cicadelídeos dos citros.}

No presente experimento não se observou diferenças de pousos entre as quatro faces da planta (norte, sul, leste e oeste), como encontrou Timmer et al. 1982. Estes autores realizaram um experimento com Oncometopia nigricans na Florida, onde encontraram um número significativamente maior de indivíduos presos às armadilhas situadas nas faces norte das plantas. 
A grande maioria das cigarrinhas preferiram pousar nos terços médio e superior (figura 18). $\mathrm{O}$ número de cigarrinhas que pousaram no terço superior foi quase $\mathrm{o}$ dobro das que pousaram no terço médio, para todas as armadilhas exceto a amarelo limão, cuja superioridade foi da ordem de $17 \%$.

Houve menos captura de insetos nas plantas tratadas com cola do que nas que continham armadilhas. Nota-se que as cigarrinhas capturadas nas plantas tratadas com cola, apresentaram uma razão sexual de cerca de 1:1, excetuando-se apenas a espécie D. costalimai cuja relação mostrou cerca de 1,5:1 ( figura 17). Estas razões sexuais diferiram daquelas obtidas com as armadilhas amarelo-ouro e amarelo limão. Nas plantas com cartões adesivos amarelo-ouro, houve um aumento de cerca de $30 \%$ no número de cigarrinhas capturadas (figura 17). Nas plantas com cartões adesivos amarelo-limão, o aumento foi de $52 \%$, sugerindo que os cartões amarelo ouro e amarelo limão são realmente atrativos a estes insetos mas sendo este último mais atrativo que os amarelo-ouro. A espécie $D$. costalimai parece ser muito pouco atraída por armadilha amarelo-ouro, pois só houve aumento significativo da captura desses insetos com as armadilhas amarelo-limão (figura 17). Pode-se observar, também, que, a razão sexual encontrada foi menor quando se usaram cartões adesivos, indicando que a cor amarela pode atrair mais machos do que as fêmeas de uma população local. Segundo os resultados do experimento de distribuição vertical, de forma geral, os machos de cicadelídeos dos citros tenderam a sair da planta mais cedo do que as fềmeas, e permaneceram mais tempo saindo da planta. Como o horário encontrado de maior atividade dos machos é plenamente iluminado, estes apresentam maiores possibilidades de enxergar as armadilhas do que as fêmeas, principalmente de D. costalimai e $O$. facialis, as quais saíram mais ao entardecer, quando a intensidade de luz já não era tão grande. De fato, grande parte das fềmeas coletadas nas armadilhas, precisamente $38,1 \%$ (figura 21 ), foram encontradas nas avaliações das 10:30 horas, fenômeno que seria explicado pelo fato de a possibilidade das fêmeas enxergarem as armadilhas neste horário ser maior que ao entardecer. 


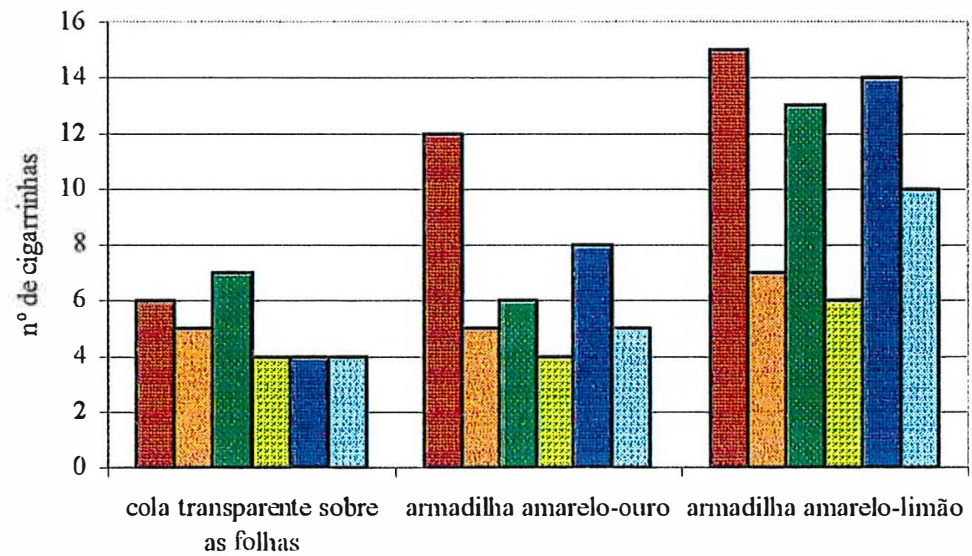

Figura 17 Número de cigarrinhas que pousaram em folhas impregnadas com cola transparente e número de cigarrinhas que pousaram em cartões adesivos amarelo-ouro e em cartões adesivos amarelo-limão durante 5 dias em um pomar em Catanduva-SP. em Maio de 1998. 


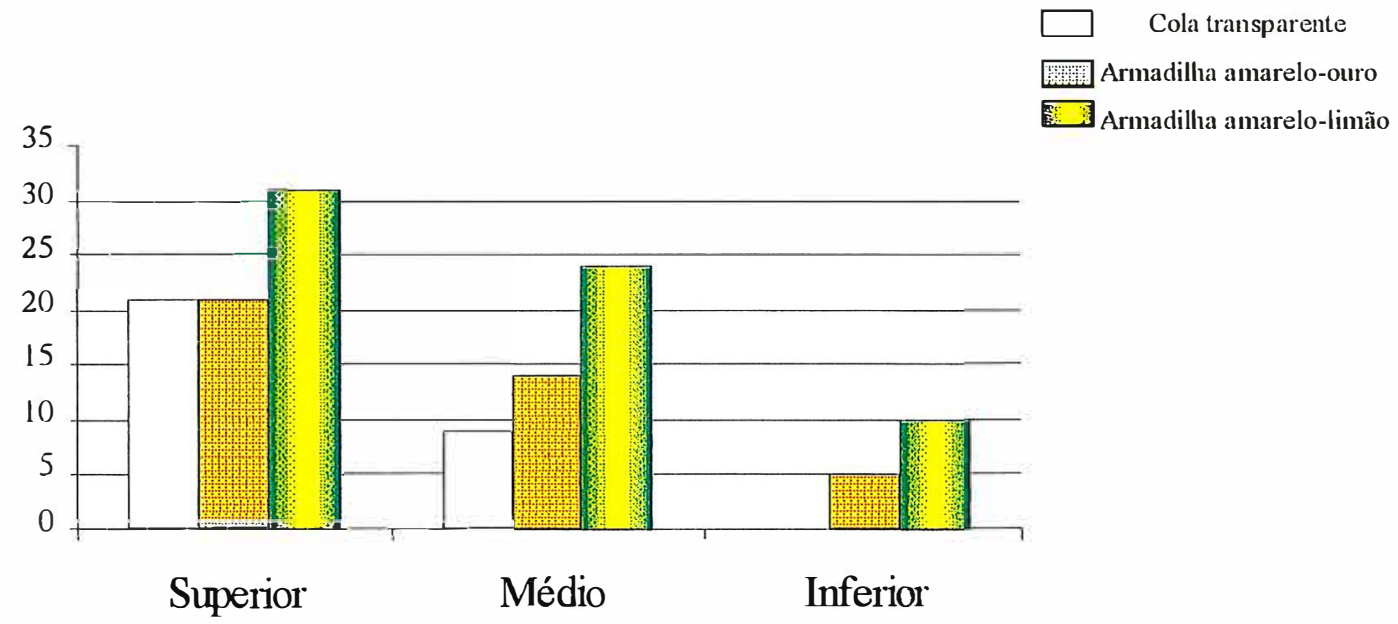

Figura 18 Número total de cigarrinhas que pousaram na cola transparente sobre as folhas, em cartões adesivos amarelos ouro e amarelo-limão durante 5 dias seguidos em pomar comercial do município de Catanduva-SP em Maio de 1998. 


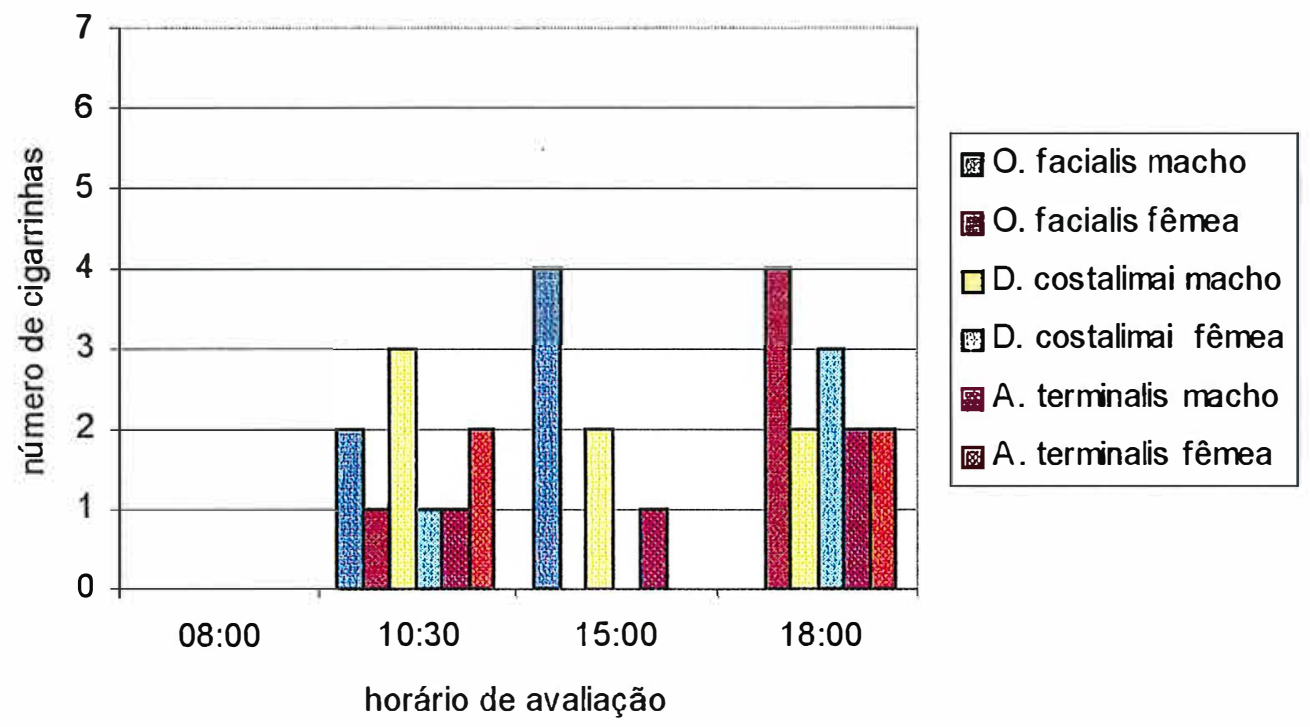

Figura 19. Número de cigarrinhas que pousaram em plantas com cola em diferentes horários do dia. Dados cumulativos de 5 dias em pomar da região de Catanduva-SP em Maio de 1998. 


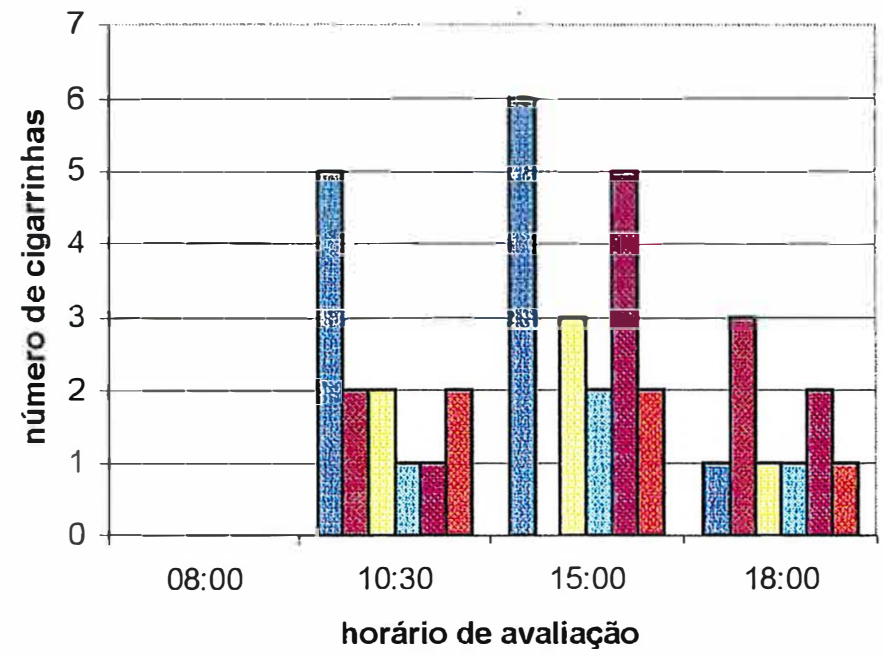

圆 O. facialis macho 圆 O. facialis fêmea

$\square \mathrm{D}$. costalimai macho 圆D. costalimai fêmea

A. terminalis macho

图A. terminalis fêmea

Figura 20. Número de cigarrinhas que pousaram em cartões adesivos amarelo-ouro em diferentes horários do dia. Dados cumulativos de 5 dias em pomar da região de Catanduva-SP em Maio de 1998. 


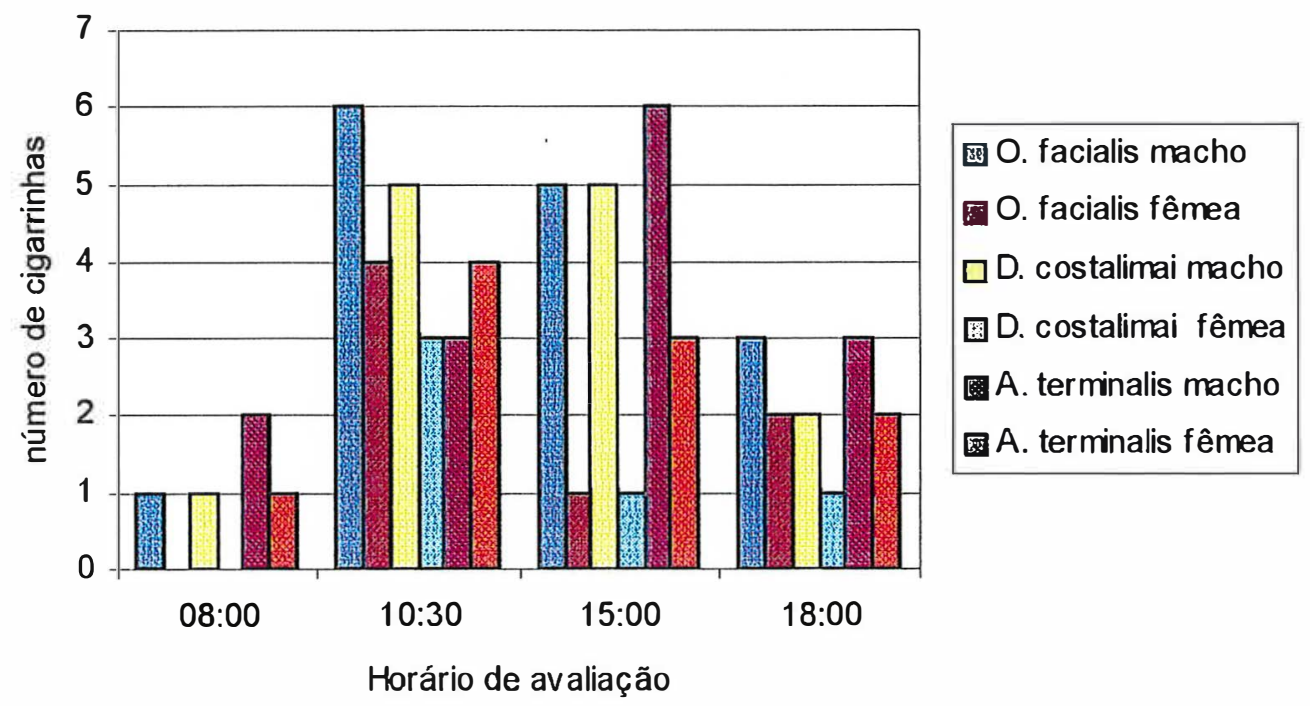

Figura 21. Número de cigarrinhas que pousaram em cartões adesivos amarelo-limão em diferentes horários do dia. Dados cumulativos de 5 dias em pomar da região de Catanduva-SP em Maio 1998.

Conclui-se que o uso da cola transparente e inodora integrou um método eficiente para se realizar o estudo de local de pouso dos cicadelídeos, pois a mesma 
não exerceu função de atração. Este método pode vir a ser útil para realizar estudos nos quais a razão sexual natural ocorrente em uma área deva ser retratada com maior verossimilhança possível.

Pode-se presumir que o uso de cartões adesivos é um recurso que pode ser útil ao monitoramento de cicadelíddeos dos citros, no entanto, cartões amarelo-ouro seriam ineficientes para se monitorar cigarrinhas em áreas que ocorram Dilobopterus costalimai, uma vez que indivíduos dessa espécie são pouco atraídos por esta cor. $\mathbf{O}$ uso de cartões adesivos amarelo-limão pareceu dar uma boa referência da população desses vetores em um pomar. Embora ele não mostre a proporção exata ocorrente entre os sexos, poder-se-ia constituir em um instrumento de monitoramento preliminar ao levantamento visual, feito por pragueiros.

\subsection{Ação do vento na dispersão de cicadelídeos dos citros.}

Observou-se que ventos de até $5 \mathrm{~m} / \mathrm{s}$ não interferiram na saída de cigarrinhas da planta cítrica. Ventos de $12 \mathrm{Km} / \mathrm{h}$ fizeram com que $50 \%$ das cigarrinhas testadas se desprendessem das mudas e ventos de $21 \mathrm{~m} / \mathrm{s}$ fizeram sair a totalidade das cigarrinhas testadas. 
Tabela 6. Número de individuos de Oncometopia facialis retirados das folhas por ventos de diferentes velocidades.

\begin{tabular}{cccccccc}
\hline $\begin{array}{c}\text { Velocidades } \\
\text { de vento } \\
(\mathbf{m} / \mathbf{s})\end{array}$ & A & B & C & D & Soma & Média \\
\hline 3 & 1 & 0 & 0 & 0 & 1 & 0,25 & $\mathrm{e}$ \\
$\mathbf{5}$ & 1 & 0 & 0 & 1 & 2 & 0,50 & $\mathrm{de}$ \\
$\mathbf{9}$ & 2 & 1 & 1 & 1 & 5 & $1,25 \mathrm{~cd}$ \\
$\mathbf{1 2}$ & 2 & 2 & 1 & 2 & 7 & $2,00 \mathrm{bc}$ \\
$\mathbf{1 5}$ & 4 & 3 & 2 & 2 & 11 & $2,75 \mathrm{ab}$ \\
$\mathbf{1 8}$ & 3 & 3 & 3 & 4 & 12 & $3,00 \mathrm{ab}$ \\
$\mathbf{2 1}$ & 4 & 4 & 4 & 4 & 16 & $4,00^{\mathrm{a}}$ \\
$\mathbf{2 5}$ & 4 & 4 & 4 & 4 & 16 & $4,00^{\mathrm{a}}$ \\
Testemunha & 1 & 2 & 2 & 2 & 7 & $1,75 \mathrm{bc}$ \\
\hline
\end{tabular}

DMS $=0,4597$

Coeficiente de variação $=12,35 \%$

Ventos a partir de $20 \mathrm{~m} / \mathrm{s}$ retiraram todas as cigarrinhas existentes na muda cítrica (tabela 6). Em situação de campo, é possível que os ventos dessa natureza retirem todas as cigarrinhas da periferia da copa, porém os insetos existentes no interior da copa, não devem sofrer a ação de toda a intensidade desses ventos, pois as folhas das copa podem servir de anteparo e assim, reduzirem a velocidade do vento que realmente atinge as cigarrinhas. $O$ número de cicadelídeos que saíram das plantas nas quatro repetições das testemunha foram, 1 , na repetição $A, 2$, na repetição $B, 2$, na repetição $C$ e 2 na repetição $D$, durante os 15 minutos testados. Comparando-se 
este resultado com os dados obtidos dos tratamentos, fica evidente, que a medida que a velocidade do vento aumentou, os insetos tenderam a permanecer na planta. No entanto depois de uma certa velocidade de vento, as cigarrinhas parecem ser arrancadas pela ação mecânica do vento. Sem vento, ou seja, na testemunha, cerca de $50 \%$ dos indivíduos abandonaram a planta para ir para outra mais iluminada, e com vento, foi necessária uma velocidade de $12 \mathrm{~m} / \mathrm{s}$ para retirar uma quantidade de cigarrinhas igual às que saíram espontaneamente na testemunha. Portanto $12 \mathrm{~m} / \mathrm{s}$ pareceu ter sido a velocidade de vento que serve de ponto de inflexão entre a tendência à permanência na planta e a tendência a saírem. Pode-se concluir que, sob as condições do experimento, os cicadelídeos dos citros não tenderam a usar o vento para realizar um vôo até a outra planta. Taylor (1974) relatou que, para vôos migratórios de outros cicadelídeos como Empoasca fabei, os insetos aproveitam o vento para se deslocarem. Taylor (1989) afirma que para fazer um inseto engajar no transporte pelo vento, a velocidade do vento tem que exceder à do inseto. Note-se que a velocidade de vôo de Oncometopia sp, segundo Bevenga et al.(1998) é de 15 $\mathrm{Km} / \mathrm{h}$ ou $4,1 \mathrm{~m} / \mathrm{s}$. Portanto, para que este inseto viaje em uma corrente de vento, ele precisa estar voando sobre a planta quando passar a corrente com velocidade superior a $4,1 \mathrm{~m} / \mathrm{s}$, o que quase não ocorre na região de Piracicaba onde a média dos ventos não ultrapassa $3 \mathrm{~m} / \mathrm{s}$ (Ometto, 1991). De uma maneira geral, os resultados do experimento de período de atividade, mostraram que os insetos tenderam a ter mais atividade de vôo no período vespertino, quando na região de Piracicaba, ventou menos que no período matutino durante o outono daquele, época em que foram realizados estes experimentos. Isto pode ter sido mais uma indicação de que as cigarrinhas dos citros, se locomoveram, dentto do pomar, muito mais por movimentação ativa, o que concorda com os resultados do experimento de dispersão, que mostrarathi úm deslocamento totalmente possítuel de ser alcançado com vôo ativo. 


\section{CONCLUSÕES}

Os cicadelídeos dos citros apresentam baixa capacidade de dispersão;

Dentre as três espécies estudadas quanto a dispersão Oncometopia facialis se dispersa mais, 37 metros em 5 dias;

Acrogonia sp. e Dilobopterus costalimai tenderam a se dispersarem de uma planta no centro de um talhão em direção à mata, e dispersaram-se $37 \mathrm{~m}$ e $22,5 \mathrm{~m}$ respectivamente, em 5 dias.

As três espécies estudadas preferiram se localizar nos terços médio e superior da planta;

Acrogonia sp. preferiu folhas jovens;

Dilobopterus costalimai preferiu ramos novos folhas jovens;

Oncometopia facialis é a espécie que ocupou a maior diversidade de tipos de órgãos vegetais e alturas da planta cítrica; 
Houve um movimento horizontal, no sentido da periferia para o interior da copa, de Acrogonia sp. e Dilobopterus costalimai quando as condições microclimáticas lhes foram desfavoráveis, ou seja, quando se eleva a temperatura na periferia da copa;

Acrogonia sp. apresentou horário de saída da planta similar para machos e fêmeas;

Machos de Dilobopterus costalimai e Oncometopia facialis saíram da planta mais cedo (às 10:30h e 13:30h), que as fêmeas; estas saíram mais ao entardecer, às 17:30horas;

O local de pouso preferido das três espécies foi o terço superior da copa da árvore cítrica. $\mathrm{O}$ órgão vegetal do citros onde as cigarrinhas pousaram foi a folha;

A ação do vento em indivíduos de $O$. facialis fixos a uma planta faz, com que eles tenham um comportamento de não sair da planta;

O. facialis não voam quando há ventos com velocidade superior a $12 \mathrm{~m} / \mathrm{s}$;

Para se tirar cigarrinhas da parte externa da planta foi necessário vento de $20 \mathrm{~m} / \mathrm{s}$. 


\section{REFERÊNCIAS BIBLIOGRÁFICAS}

ABECITUS. A história da Laranja http://abecitrus.com.br/historia.html. p.5, 05/99

ADLERS, W. C.; BLISTINE, F. W.; RUSSO, L. W.; HOPKINS, D. L. Rate of spread of citrus blight reduced when sharpshooter leafhoppers(Homoptera: Cacadellidae) are controlled. Journal of Economic Entomology, 1989, v.82 n. 6, p 733-1737.

ALMEIDA, R. P. P. de; Lopes, J, R. S. Dinâmica populacional de cigarrinhas (Hemiptera : Cicadellidae) associadas à clorose variegada dos citros. In SIMPÓSIO DE INICIAÇÃO CIENTÍFICA DA UNIVERSIDADE DE SÃO PAULO, 5, São Paulo, 1997. Simpósio de Iniciação Científica da Universidade de São Paulo,7, São Paulo, EDUSP,1997, p.470.

AMARAL, A. L. do; Paiva, L. V.; Souza, M. de. Efeito da poda em laranjeiras 'Valência' e 'Pera Rio' [Citrus sinensis (L.) Osbeck] com sintomas de Clorose Variegada dos Citros (CVC). Ciência e Prática, Lavras, v.18, n.3, p.306-307, 1994.

AMARO, A. A.; MAIA, L. Estrutura do mercado de suco cítrico no Brasil. Laranja, Cordeirópolis, v.15, n. 1, p.55-68, 1994. 
BERETTA, M.J.G.; LEE, R.F.; DERRICK, K.S.; DAVIS, C.L. \& BARTH, G.A. Culture and serology of Xilella fastidiosa associated with citrus variegad chlorosis in Brazil. International Society of Citriculture, Proceedings. 1992.

BEVENGA, S. R.; SILVA, J. L. da; PAIVA, P. E. B.; GRAVENA, R. GRAVENA, S. Capacidade de vôo das cigarrinhas Acrogonia terminalis, Dilobopterus costalimai e Oncometopia facialis. em campo aberto e em pomar de laranja. citros. In: CONGRESSO BRASILEIRO DE ENTOMOLOGIA, 17. Rio de Janeiro - RJ, 1998. Resumos. Rio de Janeiro SEB, 1998. p.270.

BOTEMBERG, H, \& LITSINGER, J. A. Using fluorescent dye to map dispersal pattern of rice gree leafhopper. International Rice Research Newsletter. Philippines, 1989, v.14: n.6, p.25-26.

CHANG, C. J.; GARNIER, M.; ZREIK, I.; ROSSETTI, V. \& BOVÉ, J. M. Citrus variegad chlorosis: cultivation of the causal bacterium and experimental reproduction of the disease. In: CONFERENCE OF THE INTERNATIONAL ORGANIZATION OF CITRUS VIROLOGISTS, 12., Riverside, 1993. Proceedings p.294-300.

COLETTA FILHO, H. D.; CARLOS, E. F.; MACHADO, M.A. Distribuition of Xilella fastidiosa within sweet oranges trees. In: INTERNATIONAL ORGANIZATION OF CITRUS VIROLOGIST, 10., Cordeirópolis, 1998. Proceedings. p.155.

COLL, O. $\mathrm{R}$ de. Chlorosis variegada de los citrus en plantaciones de la zona de Montecarlo, Missiones, Argentina. Estudio sistematico y bioecologico de los cicadelidos (Homoptera: Cicadelidae) potenciales vectores del patogeno. Buenos Aires, Argentina, 1996. 290 p. Dissertação (Mestrado em Proteção Vegetal)- 
faculdade de Ciencias Agrarias y Florestales de la Plata, Universidad Nacional de La Plata.

CONTRERAS, J. del V. "Pecosita" ou "falsa mancha grasienta"na Argentina. Laranja e Cia., v.31, n.6, p.4, 1992.

FRENCH, W. J. \& KITAJIMA, E. W. Ocurrence of plum leaf scaldin Brazil and Paraguai. Plant Disease Report, v.63, n. 12, p. 1035-8, 1978.

GARCIA JUNIOR, A.; MAGGIONE, C. S.; TEÓFILO SOBRINHO, J.; POMPEU JUNIOR., NEGRI, J.D. de; QUAGGIO, J. A.; BERETTA, M. J. G. GRAVENA, S. \& RODAS, V.Z. Como conviver com a CVC em São Paulo. Laranja, Cordeirópolis, v.16, n.2, p.145-154, 1995.

GOHEEN, A. C. ; NYLAND, G. \& LOWE, S. K. Association of rickettsialike organism with Pierce's disease of therapy of the disease in grapevines. Phytopathology, Saint Paul, v.63, p.341-5, 1973.

GOTTWALD, T.R.; GIDTTI, F.B.; SANTOS, J. M.\& CARVALHO, A. C. Preliminary spatial and temporal analysis of Citrus Variegated Chlorosis (CVC) in São Paulo, Brazil. In: CONFERENCE OF THE INTERNATIONAL ORGANIZATION OF CITRUS VIROLOGISTS, 12., Riverside, 1993. Proceedings. p.327-325.

GRAVENA, S. Manejo ecológico de pragas dos citros - aspectos práticos. Laranja, Cordeirópolis, v.19 n.1 p.61-78, 1998.

GRAVENA, S.; SILVA, J. L. da; BEVENGA, S. R.; GRAVENA, R. Métodos de amostragem de adultos das cigarrinhas Acrogonia gracilis, Dilobopterus costalimai e Oncometopia facialis. em citros. In: CONGRESSO BRASILEIRO 
DE ENTOMOLOGIA, 17. Rio de Janeiro - RJ, 1998. Resumos. Rio de Janeiro SEB, 1998. p.270.a

GRAVENA, S.; SILVA, J. L. da; BEVENGA, S. R.; PAIVA, P. E. B.; GRAVENA, R. Influência do controle do mato na densidade das cigarrinhas Acrogonia gracilis, Dilobopterus costalimai e Oncometopia facialis. Em pomar de laranja. In: CONGRESSO BRASILEIRO DE ENTOMOLOGIA, 17. Rio de Janeiro - RJ, 1998. Resumos. Rio de Janeiro SEB, 1998. p.271.b

HARAKAVA, R.; TEBAR, L. R.; BERETTA, L.; DE JESUS, C.B.; ALBA, A.P.C. \& BERETTA, M.J.G. Detection of Xylella fastidiosa antigens in weeds collected from citrus orchards affected by Citrus Variegated Chlorosis (CVC). Fitopatologia Brasileira, Brasília, v.19, ago., p.319. 1994. Suplemento.

HILL, B. L. \& PURCELL, A. H. Acquisition and retention of Xilella fastidiosa by na efficient vector, Graphocephala artropunctata. Phytopathology, Saint Paul, v.85, n.2, p.209-212, 1995.

HOPKINS, D. L. Xilella fastidiosa: xylem-limited bacterial pathogen of plants. Ann. Rev. Phytopathol., v.27, p.271-290, 1989.

HOPKINS, D. L \& ADLERS, W. C. Natural hosts of Xilella fastidiosa in Florida. Plant Disease, v.72, p.429-431, 1988.

HOPKINS, D. L \& MOLLENHAVER, H. H. Rickettsialike BACTERIUM ASSOCIATED WITH Pierce's diseases of grapes. Science, v.179, p.298-300, 1973. 
HUNT, R. E.; NAULT, L. R. Roles of interplant movment, accoustic comunication and phototaxis in mate-location behavior of the leafhopper Graminella nigrifrons. Behavior Ecology. Sociobiol., v.28 p.315-320.

JACOMINO, A. P.; MODESTO, J. C.; BERETTA, M. J. G.; TUBELIS, A.; LEITE, R. M. V. B. \& SALIBE, A. A. Transmissão controlada da Clorose Variegada dos Citros (CVC). Fitopatologia Brasileira., Brasília, v.18, ago., p.265, 1995. Suplemento.

KITAIIMA, E. W.; BAKARCIC, M. \& FERNANDEZ-VALIEGA, M. V. Association of rickettsialike bacteria with plum leaf scald disease. Phytopatology, Saint Paul, v. 65, p. 476-9, 1975.

KITAJIMA, E. W. ; MOHAN, S. K.; TSUNETA, M.; BLEICHER, J.; FRENCH, W. \& LEITE JUNIOR, R. P. Ocorrência de escaldadura das folhas da ameixeira nos estados de Paraná e Santa Catarina. Fitopatologia Brasileira, Brasília, v.6, jun., p.285-292, 1991.

LARANJEIRA, F. F. \& PALAZZO , D. A. Determinação preliminar dos efeitos da Clorose Variegada dos Citros em características físico-químicos de frutos de laranja Natal. Fitopatologia Brasileira, Brasília, v.19, ago., p.309, 1994. Suplemento.

LARANJEIRA, F. F.; HARAKAVA, R. R.; CARVALHO, S. A.; POMPEU JUNIOR, J. \& FIGUEIREDO, J. O. Avaliação serológica e sintomatológica da ocorrência de Xilella fastidiosa e Clorose Variegada dos Citros (CVC) no Banco Ativo de Germoplasma do IAC. Fitopatologia Brasileira, Brasília, v.21, ago., p.335, 1996. Suplemento. 
LARANJEIRA, F. F.; Dinâmica Espacial e Temporal da Clorose Variegada dos Citros. Piracicaba, 1997, 144p. Dissertação de mestrado, ESALQ-USP.

LARANJEIRA, F.F.; Aspectos práticos da epidemiologia da clorose variegada dos citros. Laranja, Cordeirópolis, v. 19, n. 1, p.79-90, 1998a.

LARANJEIRA, F. F.; BERGAMIN FILHO, A.; AMORIM, L. Dinâmica e estrutura de focos da clorose variegada dos citros(cvc). Fitopatologia Brasileira, Brasília, v.23, n.1, p.36-41, 1998b.

LARSEN, K.J.; WHALON, M.E. Dispersal of Paraphlesius irroratus (Say) (Homoptera: Cicadelidae) in Peach and Cherry Orchards. Enviromental Entomology. 1988, v.17, n.5, p. 842-851.

LEE, R; BERETTA, M. J. G. \& DERRICK, K. Clorose Variegada dos Citros: uma nova e destrutiva doença dos citros no Brasil. Laranja, Cordeirópolis, v.12, n.2 p.357-363, 1991.

LEE, RF.; BERETTA, M. J. G.; HARTUNG, J. H.; HOOKER, M.E. \& DERRICK,K.S. Citrus vriegated chlorosis: confirmation of a Xilella fastidiosa as the causal agent. Summa Phytopathologica, Jaguariuna, v.19, p.123-125, 1993.

LEITE JUNIOR, R.P, \& LEITE, R.M.V.B.C. Associação de Xilella fastidiosa com a Clorose Variegada dos Ciros. Summa Phytopathologica, Jaguariuna, v.17, n.1, p.1, 1991.

LIMA, J. E. O. de ; ROBERTO, S. R. \& COUTINHO, A. Clorose variegada dos citros - cigarrinhas predominantes em plantas cítricas. In: CONGRSSO 
BRASILEIRO DE FRUTICULTURA, 13., Salvador, BA, 1994. Anais. Salvador, BA, 1994. p.376.

LIMA, J. E.O. de. A pesquisa sobre o amarelinho no FUNDECITRUS. Laranja, Cordeirópolis, v.16, n.2, p.137-144, 1995.

LIMA, J.E.O. de; MIRANDA, V. S.; COUTINHO, A.; ROBERTO, S. R.; CARLOS, E.F. Fitopatologia Brasileira. Brasília, 1996, v.21, n.3, p.392-393.

LOPES, J. R. S.; NALT, L.R. \& PHELAN, P. L. Periodicity of diel activiy of Graminella nigrifrons (Homoptera: Cicadellidae) and implications for leafhoper dispersal. Annals Entomological Society of America, v.88, n.2, p.228-233, 1995.

LOPES, J. R. S.; BERETTA, M. J. G.; MARAKAVA, R.; ALMEIDA, R. P. P.; KRÜGNER, R.; GARCIA JUNIOR, A. Confirmação da transmissão por cigarrinhas do agente causal da clorose variegada dos citros, Xylella fastidiosa em cafeeiro no Brasil. Fitopatologia Brasileira, v. 21 p.343, 1996.

LOPES, J. R. S.; Mecanismos de transmissão de Xylella fastidiosa por cigarrinhas. Laranja, v. 17, n. 1, p. 79-92, 1996.

LOPES, J. R. S.; NAVAS, S. M. \& LOPES, M. T. V. de. Preferência para alimentação de cigarrinhas dos citros Dilobopterus costalimai e Oncometopia sp. (Hemiptera: cicadellidae) em diferentes espécies vegetais. In: CONGRESSO BRASILEIRO DE ENTOMOLOGIA, 16. Salvador-BA., 1997. Resumos. : Salvador: SEB, 1997. p.235.

LOPES, J. R. S.; GIUSTOLIN, T. A.; MARRUCCI, R. C.; TAKIMOTO, J. K.; MENDES, M.A.. Composição de espécies de cigarrinhas (Hemiptera: 
Auchenorrincha) em café e citros na região de Bebedouro, SP. In: CONGRESSO BRASILEIRO DE ENTOMOLOGIA, 17. Rio de Janeiro - RJ, 1998. Resumos. Rio de Janeiro SEB, 1998. p.270.

MACHADO, M.A.; SILVÉRIO, J.L.; BAPTISTA, C. R.; LARANJEIRA, F. F. \& BERETA, M. J. G. Avaliação de transmissão e seleção de variedades à clorose variegada dos citros(II). Laranja, Cordeirópolis, v.14, n.1, p.163-176, 1990.

MARTINSON, T. E.; DENNEHY, T. J.; HOFFMAN, Phenology, within vineyard distribution, and seasonal movment of eastern grape leafhopper (Homoptera: Cicadellidae) in New York vineyards. Enviromental Entomology. v.23 p.236243, 1994.

NEVES, E. M. ; Citricultura Paulista: I,mportância Econômica e Perspectivas. Laranja , Cordeirópolis v.13, n.1, p.55 - 62, 1992.

NOVOTNY, V. Relationsheeps between life histories of leafhoppers (Auchenorryncha : Hemiptera) and their host pants (juncaceae, Cyperaceae, Poacea). Oikos. v.73, n.1, p.33-42, 1995.

OMETTO, J.C. Registros e estimativas de parâmetros meteorológicos da região de Piracicaba, SP. Piracicaba, FEALQ, 1991. 76p.

PAIVA, P. E.; SILVA, J. L. da; GRAVENA, S. \& YAMAMOTO, P. T. Cigarrinhas de xilema em pomares do estado de São Paulo. Laranja, Cordeirópolis, v. 17, n.1, p. 41-54, 1996.

PALAZZO, D.A. \& CARVALHO, M. L. V. Desenvolvimento e progresso da clorose variegada dos citros(CVC) em pomares de Colina, SP. Laranja, Cordeirópolis, v.13, n.2, p.489-502, 1992. 
PALAZZO , D.A. \& CARVALHO, m. L. V. Estimativas de perdas em laranja Natal, por Clorose Variegada dos Citros (CVC), nasa colheitas de 1991/92, em ColinaSP. Fitopatologia Brasileira, Brasília, v.18, ago., p.295, 1993.

PARADELA FILHO, O; SUGIMORI, M.H.; RIBEIRO, I. J. A.; MACHADO, M. A.; LARANJEIRA, F. F.; GARCIÁ JUNIOR, A.; BERETTA, M. J. G.; HARAKAWA, R.; RODRIGUES NETO, J. \&BERIAM, L. O. S. Primeira constatação em cafeeiro no Brasil, da xilella fastidiosa causadora da Clorose variegada dos Citros. Laranja, Cordeirópolis, v.16, n.2, p.135-136, 1995.

POMPEU JUNIOR, J.; LARANJEIRA, F.F.; HARAKAWA, R. \& BERETTA, M. J. G. Primeiras constatações de sintomas foliaresde Clorose Variegada dos Citros em tangerinas e híbridos de tangerina. Fitopatologia Brasileira, Brasilia, v.19, ago., p.318, 1994. Suplemento.

PURCELL, A. H. Spatial patterns of Pierce's disease in the Napa Valey. Am. J. Enol. Vitic., v.25, n.3, p.162-7, 1974.

PURCELL, A. H. Role of the blue-green sharpshooter, Hordinia cirellata, in the epidemiology of pierce's disease of grapevines. Enviromental Entomology v.4, n. 5, p. 745-52, 1975.

PURCELL, A. H. Control of blue-green sharpshooter and efectson the spread of Pierce's disease of grapevines. Journal of Economic Entomology, v.72, p.88798, 1979.

PURCELL, A. H. Advanceds in the understanding of Pierce's disease and its insects vectors. In: GRAPE AND WINE SYMPOSIUM, 1980, Daves. Daves: University of California, 1980, p.46-50. Proceedings. 
PURCELL, A. H. Insect vector relationshhips with procarioticplant patogens. Ann. Rev. Phytopathol., v.20, p.397-417, 1982.

PURCELL, A. H. Homopteran transmission of Xylen-inhibiting bacteria. Adv. Vector Res., v.6, p.2433-66, 1989.

PURCELL, A. H. Cigarrinhas na cultura de citros. In: SEMINÁRIO INTERNACIONAL DE CITROS, MIP, I, 1994, Bebedouro.1994 Anais. Campinas: Fundação Cargill, 1994. p.195-2 Resumos.

PURCELL, A. H. \& FRAZIER, N. W. Habitats and dispersal of the principal leafhopper vectors of Pierce's disease bacterium in the San Joaquin Valey. Hilgardia, v.53, n.4, p.1-32, 1985.

PURCELL, A. H. \& ELKITON, J.S. A comparison of sampling metghod for leafhopper vectorsof X-disease in California cherry orchards. Journal of Economic Entomology, v.73, p.854-60, 1980.

PURCELL, A. H. \& FINLEY, A. H. Acquisition and transmission of bacteria through artificial membranes by leafhopper vectors of Pierce's disease. Ent. Exp. \& Appl., v.25, p.188-95, 1979

RAJU, B.C. \& WELLS, J. M. Disease caused by fastidiosa xylem-limited bacteria. Plant Disease, v.70, p. 102-180, 1986.

ROBERTO, S. R.; COUTINHO, A.; MIRANDA, V. S. \& LIMA, J. E. O. Associação entre a Clorose variegada e as cigarrinhas do xilema predominates em citros. Fitopatologia Brasileira, Brasília, v. 20, ago., p348, 1995. Suplemento. 
ROBERTO, S. R.; COUTINHO, A.; MIRANDA, V. S.; LIMA, J. E. O; MIRANDA, V. S. \& CARLOS, E. F. Transmissão de Xilella fastidiosa pelas cigarrinhas Dilobopterus costalimai, Acrogonia terminalis e Oncometopia facialis (Hemiptera: Cicadellidae) em citros. Fitopatologia Brasileira, Brasília, v.21, p.517-18, 1996.

ROBERTO, S. R.; COUTINHO, A.; MIRANDA, V. S.; LIMA, J. E. O.; MIRANDA, V. S.; CARLOS, E. F. Avaliação de métodos de monitoramento de cigarrinhas transmissoras da clorose variegada dos citros. Revista Brasileira de Fruticultura, v.19, n.2, p.123,1997.

ROSSETTI, V.; CARVALHO, M. L. V. \& CHAGAS, C.M. Ensaios de transmissão de Clorose Variegada dos Citros (CVC) em campo. Fitopatologia Brasileira, Brasília, v.20, ago., p.351, 1995. Suplemento.

ROSSETTI, V. \& NEGRI, J.D. de. Clorose Variegada dos Citros -Revisão. Laranja, Cordeirópolis, v.11, n.1, p.1-14. 1990.

ROSSETTI, V. Resultados preliminares de estudos sobre uma nova anomalidade dos citros observada nos estados de São Paulo e Minas Gerais. Summa Phytopathologica, Jaguariuna, v.16, p.13, 1990.

SILVEIRA NETO, S.; NAKANO, O.; BARBIN, D. \& VILLA NOVA, N. A. Manual de Ecologia de Insetos. São Paulo, Ed. Agronômica Ceres, 1976. 419p.

SOUTHWOOD, T. R. E. Ecological methods (with particular reference to the study of insect populations) $2^{\mathrm{a}}$ ed., London, Chapman and Hall, 1987. 524p.

TAYLOR, L. R. Insect migration, flightperiodicity and the boundary layer. Journal of Animal Ecology. V.43 p. 225-238, 1974. 
TAYLOR, R. A. J. Migratory behavior in the Auchenorryncha, In: NAULT, L. R.; RODRIGUEZ, J. G. The leafhoppers and Planthoppers. Willey, New York, 1985 , p. 259-288.

TAYLOR, R. A. J. Potato leafhooper migration: the mystery of the return migration. Misc. Publ. Entomol. Soc Am. v.72, p. 18-22, 1989.

TEBAR, L. R.; HARAKAVA, R.; GRAVENA, S.; YAMAMOTO, P.T.; PAIVA, P.E.B.; ALBA, A. P. C.; BERETA,M.J.G.; LEE, R. F. \& DERRIC, K.S. Detection of Xylella fastidiosa antigens in sharpshooter leafhopper collected from citrus orchards affected by citros clorose variegada. Fitopatologia Brasileira, Brasília, v.19, ago., p.319, 1994. Suplemento.

TRAVENSOLO, R. F. \& LEITE JUNIOR, R. P. Hospedeiros alternativos de . Xilella fastidiosa entre plantas invasoras de pomares de citros com clorose variegada. . Fitopatlogia Brasileira, Brasília, v. 21, ago., p. 336, 1996. Suplemento.

TIMMER, L. W.; LEE, R. F.; ALLEN, J.C.; TUCKER, D. P. H. Distributions of Sharpshooters in Florida Citrus Groves. Enviromental Entomology. v.11, n.2, p.456-460, 1982.

TUBELIS, A.; BERETA, M.J.G. \& RODRIGUES NETO, J. Primeira constatação da Clorose Variegada dos Citros (CVC) no Distrito Federal. Fitopatologia Brasileira, Brasília, v.18, ago. p.312, 1993. Suplemento.

TURNER, W. F. \& POLLARD, H. N. Insect transmission of phony peach disease. Daves: U.S. Dept. of. Agriculture, 1959. 27p. (Technical Bulletin, 1193).

WELLS, J.M.; RAJU, B. C.; HUNG, H. Y.; WEISBURG, W. G.; MANDELCOPAUL, L.; BRENNER, D. J. . Xylella fastidiosa new-genus new- 
species: Gran negative xylem-limites fastidious plant bacteria related to Xanthomonas spp. Int. J. Syst. Bacterol., v.37, p.136-43, 1987.

YAMAMOTO, P.T. Espécies e flutuação populacional de cigarrinhas e psilídeos (Hemiptera) em pomares cítricos. Jaboticabal, 1998. 112p. UNESP-Tese (Doutorado). Faculdade de Ciências Agrárias e Veterinárias-UNESP.

YAMAMOTO, P. T.; GRAVENA, S. Espécies de cigarrinhas (Hemiptera: Cacadellidae) em pomares cítricos no estado de São Paulo.. In: CONGRESSO BRASILEIRO DE ENTOMOLOGIA, 17. Rio de Janeiro - RJ, 1998. Resumos. Rio de Janeiro SEB, 1998. p. 270. 